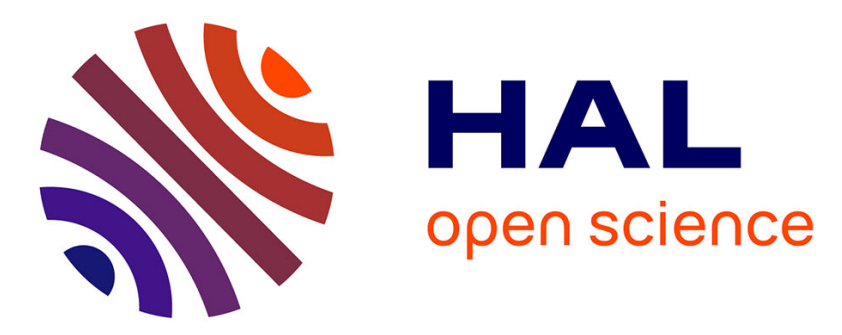

\title{
Strain partitioning within bending orogens, new insights from the Variscan belt (Chiroulet-Lesponne domes, Pyrenees)
}

Bryan Cochelin, Baptiste Lemirre, Yoann Denèle, Michel de Saint Blanquat

\section{- To cite this version:}

Bryan Cochelin, Baptiste Lemirre, Yoann Denèle, Michel de Saint Blanquat. Strain partitioning within bending orogens, new insights from the Variscan belt (Chiroulet-Lesponne domes, Pyrenees). Tectonics, 2021, 40 (7), pp.e2020TC006386. 10.1029/2020TC006386 . hal-03276362

\section{HAL Id: hal-03276362 https://hal.science/hal-03276362}

Submitted on 8 Jul 2021

HAL is a multi-disciplinary open access archive for the deposit and dissemination of scientific research documents, whether they are published or not. The documents may come from teaching and research institutions in France or abroad, or from public or private research centers.
L'archive ouverte pluridisciplinaire HAL, est destinée au dépôt et à la diffusion de documents scientifiques de niveau recherche, publiés ou non, émanant des établissements d'enseignement et de recherche français ou étrangers, des laboratoires publics ou privés. 
1 Strain partitioning within bending orogens, new insights from the Variscan

\section{belt (Chiroulet-Lesponne domes, Pyrenees)}

3

$+$

$5 \quad{ }^{1}$ BRGM DGR/GSO, BP 36009, 45060 Orléans, France

$62^{2}$ Géosciences Environnement Toulouse, Université de Toulouse, CNRS, IRD, UPS, CNES,

$7 \quad 31400$ Toulouse, France

$8{ }^{3}$ Université d'Orléans, CNRS, BRGM, ISTO, UMR 7327, 1A Rue de la Ferollerie, 45071

9 Orléans, France

${ }^{4}$ State Key Laboratory for Mineral Deposits Research, Nanjing University, Nanjing 210093, China

1) ${ }^{5}$ DREAL Grand Est, SPRNH/PSO/UPC SAMA, 51000 Châlons-en-Champagne, France

1) Submitted to Tectonics, 17 June 2020

14

Revised 11 June 2021

$\perp$

$16 *$ Corresponding author: Bryan Cochelin (bryan.cochelin.get@gmail.com)

\section{Key points:}

- The Variscan crust of Pyrenees documents vertical strain partitioning: lateral flow vs upper-

19 crust thickening in the core of Pangea

20 - We document horizontal strain partitioning between extensional and compressional domains

$\measuredangle 1$ during plate-scale oroclinal bending

This article has been accepted for publication and undergone full peer review but has not been through the copyediting, typesetting, pagination and proofreading process, which may lead to differences between this version and the Version of Record. Please cite this article as doi: 10.1029/2020TC006386.

This article is protected by copyright. All rights reserved. 
22 - Large-scale strain patterns of bending hot orogens reflect initial conditions (at the onset of

23 bending) and evolving free-boundaries

\section{Abstract}

25 This study investigates how strain is partitioned within hot orogenic belts in a context of plate26 reorganization. We document crustal-scale strike-slip shear zones, plate-scale oroclinal bending,

27 and widespread exhumation of deep crustal domains in the core of nascent Pangea plate during 28 late-Variscan times (ca. 310-290 Ma). The role of strain partitioning in the finite strain patterns is 29 first highlighted at regional-scale by a new detailed structural, kinematic, and petrologic analysis 30 of the Chiroulet and Lesponne gneiss domes in the Pyrenees. Vertical strain partitioning in

31 response to N-S shortening-dominated dextral transpression is secondly documented at the scale

32 of the Variscan domains of the Pyrenees, based on a synthesis of recent geochronological, 33 thermobarometrical, and structural data. We show that the mid-lower crust is affected by 34 eastward lateral flow and the upper crust by penetrative thickening and localized thrusting. Local 35 transverse extension in the mid-lower crust illustrates gravity-driven instability favored by the 36 accumulation of anatectic melts in gneiss domes. Finally, we highlight the respective position of

37 extended and shortened area within the Variscan belt during late-Carboniferous/early-Permian 38 that suggests large-scale lateral strain partitioning and reorganization of the weak continental 39 crust in the core of the Pangea. This distribution appears significantly different from other 40 orogens in a similar context of oroclinal bending, resulting in localization of the shortened zones 41 in the core of the belt. This highlights the influence of the initial and boundary conditions, such as 42 the obliquity of the belt to the applied stress field and the location of free-boundaries, on finite 43 strain patterns. 


\section{Introduction}

45 The understanding of how convergence is accommodated by the lithosphere remains an

46 important issue in tectonics, for both recent and old orogenic belts (e.g., Conand et al., 2020;

47 Torvela \& Kurhila 2020). Mass transfer within a crust subjected to convergence can be variably

48 accommodated, depending on the rheological behavior of the colliding lithospheres (e.g., Davy,

49 1986, Brun, 2002). Under abnormally hot thermal conditions, the weak orogenic crust is

50 subjected to crustal flow and heterogeneous accommodation of strain, which is strongly

51 partitioned (Davy \& Cobbold, 1991; Gapais et al., 2009; Chardon et al., 2009; 2011). Strain can

52 be partitioned vertically, combining lateral horizontal flow (i.e., escape) within the weak lower

53 crust and thrusting along the direction of shortening within the upper crust (Cagnard et al., 2006;

54 Chardon et al., 2009; Bajolet et al., 2015). In such a context, the weak and buoyant lower crust

55 can be exhumed up to shallow levels in response to gravity instability, leading to the formation of

56 syn-convergence gneiss domes (Teyssier \& Whitney, 2002; Yin, 2004; Whitney et al., 2004;

57 Cagnard et al., 2007; Chardon et al., 2009). Strain can also be partitioned laterally, leading to the

58 coeval development of thrust, strike-slip, and extensional zones through orogens (Teyssier \&

59 Whitney, 2002; Tikoff et al., 2004). Both vertical and horizontal strain partitioning are

60 significantly enhanced in a context of orocline formation (Bajolet et al., 2013; Johnston et al.,

61 2013; Krýza et al., 2019). The Himalayan-Tibet orogenic system, bordered by the Pamir-Punjab

62 and the Namche Barwa syntaxes at its western and eastern edges, respectively, fully illustrates

63 the impact of both lateral and vertical strain partitioning in hot orogens. Indeed, strain is

64 accommodated by thrusting at the front of the belt while the ductile crust from the orogenic

65 plateau is extruded laterally and transversally, exhuming deep crustal rocks within gneiss domes

66 along with the Himalayan ranges (Tapponnier et al., 1982; Gapais et al., 1992; Clark \& Royden,

This article is protected by copyright. All rights reserved. 
67 2000; Stephenson et al., 2001; Beaumont et al., 2001; Taylor \& Yin, 2009). Lateral-escape

68 accommodation by wrenching is well-expressed at the edges of the belt, and especially in

69 response to the development of orogenic syntaxes (e.g., Searle 1996; Bosboom, et al., 2014;

70 Bajolet et al., 2015). As noticed by several authors, the Himalayan-Tibet system shares similar

71 structural patterns with the Variscan belt of Western Europe (e.g., Matte 1991, Vanderhaeghe \&

72 Teyssier, 2001). Indeed, the Variscan belt was characterized by coeval development of crustal-

73 scale, strike-slip shear zones (Fig. 1, e.g., Arthaud \& Matte, 1975; Matte, 2001; Carreras \&

74 Druguet, 2014; Díez Fernández \& Pereira, 2017), plate-scale oroclinal bending (Fig. 1, e.g.,

75 Gutiérrez-Alonso et al., 2004; Weil et al., 2010) and widespread exhumation of deep crustal

76 domains (e.g., Burg et al., 1994; Martínez Catalán et al., 2007; Gapais et al., 2015; Authemayou

77 et al., 2019). While most of the tectonic models focused on strain partitioning within the

78 collapsing hinterland, only a little attention was paid to strain patterns from the foreland of the

79 belt and the link between them was poorly investigated. But both the hinterland and the southern

80 foreland of the Variscan belt were affected by a diffuse and late reorganization of early orogenic

81 structures during the late-Carboniferous to the early-Permian period (310-290 Ma). It is

82 associated with high-to ultra-high temperature metamorphism (Pin and Vielzeuf, 1983; Barbey et

83 al., 2015; Kunz et al., 2018), and bi-modal magmatism that has affected the whole southern part

84 of the Variscan belt (Martínez Catalán et al., 2014; Moyen et al., 2017; Petri et al., 2017; Lemirre

85 et al., 2019). The widespread high-temperature event suggests lithospheric-scale thermal anomaly

86 associated with the removal of the lithospheric root (Gutiérrez-Alonso et al., 2004; Buzzi \&

87 Gaggero, 2008; Laurent et al., 2017). The southern foreland of the Variscan belt centered on the

88 Cantabrian orocline and the Variscan domain from the Pyrenees were also affected by this

89 thermal anomaly despite these domains did not suffer significant thickening before the high-

This article is protected by copyright. All rights reserved. 
90 temperature deformation event (de Saint Blanquat et al., 1990; Weil et al., 2013; Cochelin et al., 91 2017).

92 In this context, the common history of the Cantabrian orocline and the Variscan domains of the 93 Pyrenees during late-Variscan evolution remains a significant issue to understand late mountain 94 range evolution and crust-mantle interactions. The Cantabrian orocline located at the core of the 95 Iberian Armorican arc (Fig. 1), is associated with about $180^{\circ}$ of cumulative vertical rotation 96 (clockwise and counter-clockwise for the northern and the southern limbs, respectively) of early 97 orogenic structures (Weil et al., 2013; and references therein) between 305 and 295 Ma (Weil, 2006; Weil et al., 2010). Two typical strain patterns were recognized around this late-orogenic

99 structure, depending on their position within or at the limbs of the arc. The core of the arc (i.e., 100 the Cantabrian Zone) is characterized by contractional structures, such as arc-radial folds and 101 steep E-W striking thrusts (e.g., Pérez-Estaún et al., 1988; Bahamonde et al., 2007; Merino-Tomé 102 et al., 2009; Pastor-Galán et al., 2014; Blanco-Ferrera et al., 2017; García-López et al., 2018, Fig. 103 1). To the contrary, the branches of the arc (e.g., Armorican massif, Central Iberian Zone) exhibit 104 arc-parallel stretching, accommodated by both lateral wrenching and extension (e.g., Martínez 105 Catalán et al., 2007; Gapais et al., 2015; Díez Fernández \& Pereira, 2017; Authemayou et al., 106 2019). Based on this apparent opposition, it has been proposed that the cause of oroclinal bending 107 is an active buckling at lithospheric-scale that was responsible for contrasted mass transfers in the 108 arc, depending on the relative position in the inner and outer arc (Gutiérrez-Alonso et al., 2012). 109 However, compressive/transpressive tectonics is not restricted to the core of the Cantabrian 110 orocline but seems to had developed coevally in the rest of the southern Variscan belt (i.e., the 111 Gondwanan margin), such as the Alpine External Crystalline Massifs (Fréville et al., 2018), the 112 Maures-Tanneron and Corsica-Sardinia massifs (Rolland et al., 2009; Casini et al., 2015), the 
113 Meseta (Alleghenian belt, Michard et al., 2010; Delchini et al., 2018) and the Axial Zone of the

114 Pyrenees (Cochelin et al., 2017) (Fig. 1).

115 The Variscan domains of the Pyrenees provide excellent markers to study the influence of 116 combined lateral and vertical strain partitioning during structural plate reorganization that led to 117 oroclinal bending. These domains consist of a late-Variscan (i.e., 310-290 Ma) transpressive 118 segment that corresponds to the so-called Pyrenean Axial Zone and sparse massifs under 119 Mesozoic cover to the North, the North Pyrenean massifs (NPM) (Fig. 2a). The lower crust was 120 affected by lateral horizontal flow while the upper crust was strongly squeezed and affected by 121 thrusting along the direction of shortening (Cochelin et al., 2017; 2018a). This structural pattern 122 highlights a very peculiar crustal-scale type of deformation in the foreland of the Variscan belt 123 during its late structural reorganization.

124 This paper aims to clarify the role of multi-scale strain partitioning in the tectonic evolution of 125 orogenic belts subjected to a structural late-reorganization and bending by focusing on the 126 southern part of the Variscan belt, which is located in the core of Pangea during the late127 Carboniferous to early-Permian period. To address this issue, we illustrate how vertical strain 128 partitioning controlled gneiss dome formation in the Pyrenees by providing a new structural, 129 kinematics, and petrological study on the Chiroulet and Lesponne massifs, located at the north130 western corner of the Axial Zone (Fig. 2a). Coupled with a synthesis of published structural, 131 geochronological, and metamorphic data from the whole Variscan domains of the Pyrenees (Figs. $1322 \mathrm{~b} \& 2 \mathrm{c})$, these data are integrated at the scale of the southwestern Variscan belt. We highlight 133 how the interaction between localization of mantle heat source and large-scale vertical and lateral 134 strain partitioning led to the coexistence of strike-slip, compressional/transpressional, and 135 extensional/transtensional tectonic belts. By comparing the Variscan belt of Western Europe with 
136 the west Himalayan syntax, we discuss the influence of initial and boundary conditions and

137 thermal states of the colliding lithospheres on finite strain patterns in a context of lithosphere 138 bending.

\section{$139 \quad$ 2. Geological setting}

2.1 The Variscan domains of the Pyrenees in the Variscan belt

141 The Western Europe massifs (i.e., Armorican Massif, Iberian Massif, French Massif Central,

142 Bohemian massif, Fig 1) recorded a late-Carboniferous to early-Permian orogenic dismantling 143 associated with high-thermal conditions. This plate-scale event took place after a period of 144 amalgamation of a series of micro-plates with Laurussian margin and a major collisional event of 145 these amalgamated continental blocks with the Gondwana land-mass, during Devonian and 146 Carboniferous times (e.g., von Raumer et al., 2013; Edel et al., 2018; Lotout et al., 2020).

147 During the main collision phase in Western Europe massifs, the Variscan domains of the 148 Pyrenees corresponded to the distant foreland of this orogenic system that recorded deep-sea to 149 platform sedimentation at Devonian to mid-Carboniferous times (see García-Sansegundo et al., 1502011 and references therein) and ultimately turbiditic deposition (Delvolvé \& Perret, 1989). 151 Flysch deposition is associated with an early tectonic phase, called D1, that was locally preserved 152 as a relic in the Axial Zone (Cochelin et al., 2017 and references therein). Where preserved, D1 153 features are characterized in the upper crust by south-westward to westward thrusts and 154 recumbent or overturned folds (Matte, 2002; Cochelin et al., 2017). These structures induce no 155 significant stratigraphic or structural breaks and were interpreted as reflecting thin-skinned 156 tectonics in the distant foreland of the Variscan belt, between 325-310 Ma (Cochelin et al., 2017). 157 Few occurrences of foliation relics were noticed in the mid-to-lower crust but its relation with D1 
structures observed in upper crustal levels remains unconstrained (de Hoÿm de Marien et al.,

159 2019). The D1 tectono-metamorphic event in the Pyrenees is poorly recorded, but it is supposed

160 to produce moderate thickening of the crust, as exemplified by preserved occurrences of prograde

161 M1 metamorphism (Barrovian) in the Canigou massif (de Hoÿm de Marien et al., 2019, Fig. 2c).

162 A slight increase of pressure of about $1 \mathrm{kbar}$, from 5.5 to $6.5 \mathrm{kbar}$, has been reported by these

163 authors.

164 Late Variscan deformation under a high-temperature regime is responsible for the strain pattern 165 of the Variscan domains of the Pyrenees. This strain pattern is marked in the Axial Zone by two 166 distinct structural levels, the so-called Superstructure and Infrastructure (De Sitter \& Zwart, 167 1960) that corresponds to the upper and mid-lower crustal levels, respectively. The

168 Superstructure is made of low-grade Paleozoic metasedimentary rocks affected by intense folding 169 (Carreras \& Capella, 1994), an associated N100E-striking steep axial plane cleavage (Fig. 3) 170 bearing vertical stretching lineations and host the large calc-alkaline plutons (Cochelin et al., $1712017 ; 2018 a, b)$. The Infrastructure corresponds to the partially molten mid-lower crust that is 172 observed within longitudinally elongated gneiss domes (Denèle et al., 2007; 2009; Mezger, 173 2009). These gneiss domes are defined by shallowly dipping foliation planes bearing longitudinal 174 (i.e., parallel to the belt) stretching lineations (Fig. 3; Cochelin et al., 2018a). In details, the 175 Superstructure is characterized by an incomplete fan of schistosity, interrupted by Alpine faults, 176 especially the North Pyrenean Fault (NPF) to the North, with a vertical domain in the northern 177 half part of the Axial Zone and a domain of dip decreasing southward (Zwart, 1979; Cochelin et 178 al., 2018a). Geostatistical analysis of cleavage suggests that the zone affected this fan of 179 schistosity was initially 80-100 km wide (Cochelin et al., 2018a). Furthermore, the northern 180 domain localized near the NPF was mainly affected by apparently intense coaxial (i.e., non- 
181 rotational) deformation while the southern one is characterized by non-coaxial "north side up" 182 (i.e., the northern block goes upward and the southern downward) or "top to the south" shearing. 183 A dextral component of shearing is also observed and appears restricted to the vicinity of plutons 184 and gneiss domes (Cochelin et al., 2018a). Within gneiss domes belonging to the Infrastructure, 185 the direction of stretching tends to evolve vertically from E-W in the core of gneiss domes to 186 oblique or transverse at their roof (Fig. 3). There, strain localization can be observed within the 187 andalusite zone forming retrogressive extensional shear zones (Van den Eeckhout \& Zwart, 1988; 188 Mezger \& Passchier, 2003; Cochelin et al., 2017; Le Bayon \& Cochelin, 2020). The gneiss 189 domes are mostly folded, with folds showing steep or south verging overturned limbs that are 190 partially reworked by steep reverse-dextral shear zones (Carreras et al., 1980; Vilà et al., 2007; 191 Denèle et al., 2007; 2008; 2009). These reverse-dextral shear zones have been developed under 192 amphibolite-to-greenschists facies conditions and defined an anastomosed network that has 193 affected the evolution of gneiss domes (Denèle et al., 2007; Cochelin et al., 2018a) and the 194 dynamics of pluton emplacement (Gleizes et al., 1998; Denèle et al., 2008).

195 The mode of formation of the Superstructure and the Infrastructure was widely debated since the 196 '60s (e.g., see Carreras \& Capella, 1994) but a coeval formation under N-S shortening-dominated 197 transpression, called D2, reached consensus since two decades (e.g., Gleizes et al., 1998; Mezger, 198 2009; Denèle et al., 2014; Cochelin et al., 2017). Coeval formation of these two structural 199 domains was interpreted as reflecting vertical strain partitioning between a partially molten and 200 hot middle crust and the cold upper crust (Denèle et al., 2007; 2009; Cochelin et al., 2017). It 201 should be noted that this vertical structural zonation was only partially recognized in the NPM. 202 While a transpressional regime was advocated in the Trois-Seigneurs and the Agly massifs 203 (Leblanc et al., 1996; Gleizes et al., 1998; Olivier et al., 2004), the other massifs (Ursuya, 
204 Castillon, St Barthélémy) have been affected by crustal thinning, permitting the exhumation of

205 Low-Pressure granulites thanks to the activation of extensional shear zones/detachments bearing 206 mainly transverse direction of stretching (Fig. 3) (de Saint Blanquat et al., 1990; Cochelin et al., 207 2017, Saspiturry et al., 2019). In the Agly massif, crustal thinning was described as occurring 208 during dextral transpression (Olivier et al., 2004; Vanardois et al., 2020; Siron et al., 2020).

209 The late-Carboniferous/early-Permian thermal anomaly is characterized in the Variscan massifs 210 of the Pyrenees by partial melting of the mid-lower crust under Low-Pressure amphibolite facies 211 in the Axial Zone and Low-Pressure granulite facies in the NPM (Vielzeuf, 1984; de Saint 212 Blanquat et al., 1990; Guitard et al., 1996; Vilà et al., 2007; Aguilar et al., 2015, Lemirre, 2018, 213 Figs. 2c, d \& e). In details, available PT estimates for peak metamorphism show that apparent 214 metamorphic gradient within the crust of the Pyrenees at ca. $300 \mathrm{Ma}$ can be divided into two 215 parts (Figs. 2d \& e), i) a first part showing high metamorphic gradients (i.e., between 55 and $21690^{\circ} \mathrm{C} / \mathrm{km}$ ) up to ca. $3 \mathrm{kbar}$ and ii) nearly isothermal conditions within the partial molten middle 217 crust. Temperature peak in the middle crust is around $700-750^{\circ} \mathrm{C}$ within the Axial Zone and 800 $218850^{\circ} \mathrm{C}$ within the North Pyrenean Massifs, corresponding to the wet solidus and biotite 219 dehydration melting reaction respectively (Figs. 2d \& e). In most of the gneiss domes, 220 exhumation favored by extensional shearing is well imaged by clockwise PT paths (Fig. 2c), 221 implying nearly isothermal decompression (e.g., Roc de France), heating and decompression 222 (e.g., the Bossost dome), or cooling and decompression (the Albères massif, Fig. 2c). Locally, 223 decompression was followed by heating and a slight increase in pressure (e.g., the Canigou and 224 Aston domes, Fig. 2c).

225 Partial melting in the mid-lower crust is associated with intrusion of numerous large calk-alkaline 226 plutons in the upper crust (i.e., between 2 and 3 kbar, Fig. 2c) and leucogranites or mafic sills in 
227 the middle crust (i.e., for pressure higher than 3 kbar; Debon et al., 1996; Denèle et al., 2014;

228 Kilzi et al., 2016). These calk-alkaline plutons are made of successive intrusion of magmas from 229 gabbroic to granitic compositions having hybrid to mantle sources (Debon et al., 1996; Lemirre et 230 al., 2019). Magmatism mainly took place between 305 and 290 Ma, coevally with the D2 231 transpressional phase (Denèle et al., 2014; Druguet et al., 2014; Kilzi et al., 2016; Lopez-Sanchez 232 et al., 2018; Lemirre, 2018; Lemirre et al., 2019, Fig. 2b). Magmatism may have started earlier 233 locally (Aguilar et al., 2014; Lopez-Sanchez et al., 2018; Schnapperelle et al., 2020) and 234 continued up to $270 \mathrm{Ma}$ in the Basque and North Pyrenean Massifs (Fig. 2b).

237 The Chiroulet and the Lesponne massifs correspond to two neighboring gneiss domes, located in 238 the north-western corner of the Axial Zone between the Néouvielle pluton to the south and the 239 NPF to the north (Fig. 3). Forming two $15 \mathrm{~km}$ long and $5 \mathrm{~km}$ wide elliptical bodies, they 240 represent the smallest gneiss domes of the Axial Zone. The Lesponne dome sensu-lato 241 corresponds to a succession of three sub-domes, the Lesponne sub-dome sensu-stricto, the Aigue242 Rouye sub-dome, and the Gripp anticline from west to east, respectively (Fig. 4a). Along with the 243 Bossost dome located in the Central Axial Zone (Fig. 3), the Chiroulet-Lesponne domes are the 244 shallowest of the Axial Zone, as sillimanite and andalusite isograds reached the upper Paleozoic 245 series (Pouget, 1984; Ternet et al., 1996). The case of the Chiroulet massif is unique in the Axial 246 Zone because the anatectic front is located at the transition between Silurian black schists and 247 Devonian limestones while it is located in lower Paleozoic rocks in the other massifs (Guitard et 248 al., 1996 and reference therein). The core of these gneiss domes is composed of metatexites and 249 bimodal plutons (diorites and leucogranites) for the Lesponne dome, and diatexites with 
250 leucogranite sheets for the Chiroulet dome. Metamorphic conditions of partial melting have been 251 estimated at ca. $700{ }^{\circ} \mathrm{C}$ and $4.2 \mathrm{kbar}$ in the Lesponne dome (i.e., at mid-crustal depths, see 252 Lemirre et al., 2019, Fig. 2b). Geochemistry shows that the dioritic magma is associated with a 253 mantle source while leucogranites are issue from partial melting of surrounding metasedimentary 254 rocks (Lemirre et al., 2019). In the Lesponne and Chiroulet massifs, partial melting started at ca. $255303 \mathrm{Ma}$ and the final crystallization of magmas occurred at ca. $290 \mathrm{Ma}$, suggesting that the mid256 lower crust stayed hot (i.e. around $700^{\circ} \mathrm{C}$ ) and partially molten during $10 \mathrm{My}$ (Lemirre et al., 257 2019, Fig. 2c). Based on petrostructural studies, Pouget (1984, 1987) and Pouget et al., (1989) 258 have proposed that these massifs form two magmatic diapirs intruding the upper crust in a 259 context of orogenic collision. However, the absence of published mineral-stretching lineation 260 measurements or kinematic data makes it difficult to ascertain the tectonic context of their 261 formation.

\section{3. Methods}

263 This work is based on 197 field stations, where petrographic, structural and kinematic analysis 264 were performed (see Supporting Information). To retrieve how the gneiss domes were emplaced 265 within the upper crust, planar and linear strain fabrics and kinematic criteria were systematically 266 measured. The studied area is characterized by the interference between two regional penetrative 267 fabrics. The first defines the main foliation within migmatites, paragneiss, and sillimanite268 andalusite bearing micaschists. The second is an axial plane cleavage, moderately to steeply 269 dipping to the south, mainly observed in upper crustal low-grade rocks. This cleavage is marked 270 by oriented biotites and chlorites. As these two fabrics characterize respectively the Infrastructure 271 (i.e., the middle crust) and the Superstructure (i.e., the upper crust), we call them "Si" and "Ss" 272 respectively, following Cochelin et al., (2017) and consequently, the same terminology will be 
273 used for lineations ( $\mathrm{Li}$ and Ls). Specific attention was paid to the transition between $\mathrm{Si}$ and $\mathrm{Ss}$

274 fabrics and we present hereafter their structural relationship by showing the observed interference

275 patterns. These results allow us to propose a revised and harmonized geological map of the area

276 (see Supporting Information), and a structural map based on the compilation of available data and

277 our measurements (Fig. 4b). Our dataset is also presented in Figure 5. New cross-sections over

278 the two massifs (Fig. 6) and field observations (Figs. 7, 8 \& 9) are presented, highlighting

279 structural patterns within the upper and middle crust. Besides, 34 samples were collected within

280 the two gneiss domes and their surrounding metasedimentary rocks. Thin-sections were prepared

281 normal to the schistosity and parallel to the mineral-stretching lineation (XZ planes) for 282 petrographic and microstructural analysis (Fig. 10).

\section{4. Results}

284 From a structural point of view, the studied area is divided into three domains: i) the core of the 285 gneiss domes made of migmatites, plutonic rocks (e.g., leucogranite, diorite), and paragneisses, 286 where only $\mathrm{Si}$ is observed; ii) the upper crustal domain, where Ss is the main fabrics; and iii) a 287 transitional zone in-between, that has affected the Devonian rocks belonging to the sillimanite288 andalusite zone, where interference patterns between $\mathrm{Si}$ and $\mathrm{Ss}$ can be found. We present 289 hereafter these three domains from bottom to top.

290 4.1. The lower domain

291 The lower domain can be defined under the sillimanite-in isograd where gneissic rocks 292 (metatexites and paragneiss) and micaschists show evidence of plastic deformation of quartz, 293 feldspar, phyllosilicates, and alumina silicates that define the foliation $\mathrm{Si}$ and the stretching 294 lineation Li.

This article is protected by copyright. All rights reserved. 
295 The map of foliation trajectories highlights a first-order concentric pattern centered on high-grade 296 rocks that define two gneiss domes with $\mathrm{N} 110^{\circ}$ and $\mathrm{N} 130^{\circ}$ long axis, for the Lesponne and 297 Chiroulet massif, respectively (Fig. 4). Foliation trajectories in north-south cross-sections (Fig. 6) 298 show that the Lesponne dome is upright and symmetrical while the Chiroulet dome is 299 asymmetrical and inclined, with foliation dominantly dipping to the south. The northern limb of 300 the Chiroulet dome is characterized by S-steeply dipping foliation suggesting a domal shape 301 overturned to the north (Figs $4 b$ \& 6). The internal structure of the domes displays second-order 302 sub domes (Fig. 4b) with apexes that correspond to the core of magmatic bodies or diatexites in 303 the Lesponne and Chiroulet domes, respectively (Fig. 4). Magmatic rocks (leucogranites and 304 diorites) and diatexites are characterized by more or less defined magmatic foliation and lineation 305 (Fig. 7a, b \& c). Structural concordance between the intrusive contact of diorite-leucogranite 306 plutons with their country-rocks and the foliation Si suggests intrusion as magmatic sills (Figs. 6 $307 \& 7 a)$. Moreover, consistency between magmatic mineral lineations within magmatic bodies and 308 stretching lineations within their country-rocks reflects that they were deformed synchronously 309 during magmatic events. Mineral/stretching lineations are defined by elongated quartz 310 aggregates, oriented feldspars, patches of micas (Fig. 7c), or oriented amphiboles (Fig. 7d) and 311 show a consistent $\mathrm{N} 110^{\circ}$ trend in the Chiroulet dome and N130 in the Lesponne dome (Fig. 4b). 312 Stretching is associated with strain localization into shallowly dipping C' shear bands with a 313 consistent "top to the west" sense of shear (see Cochelin et al., 2017, Fig. 10c). Injection of 314 magmatic veins is common in these shear bands, suggesting deformation during partial melting. 315 At the boundary between the lower domain and the transitional domain of the Chiroulet dome, 316 stretching lineations turn to N-S (Fig. 4b) and C/S structures (following the definition by Gapais, 317 1989) can be observed within leucogranitic sills, with "top to the south" kinematics (Fig 6, see 
318 Lemirre et al., 2019). Calc-silicate gneisses at the top of the migmatites are affected by antithetic 319 slip boudinage (i.e., domino-like) compatible with "top to the south" shearing (Fig. 7e).

320 The microstructural study shows that paragneisses and sillimanite-bearing micaschists of the 321 lower domain from the two domes are characterized by strongly oriented fabrics (Figs. 10b, c \&

$322 \mathrm{~d})$. The association of deformation bands in quartz grains as well as evidence of dynamic 323 recrystallization controlled by grain boundary migration (Fig. 10b) attest to deformation at high-

324 temperature conditions, i.e. $>500^{\circ} \mathrm{C}$ (Stipp et al., 2002; Fossen and Cavalcante, 2017). In the 325 calc-silicate gneisses at the top of the migmatites, Si foliation is parallel to the transposed 326 bedding defined by the alternation of diopside-epidote-sphene layers and garnet-diopside-sphene 327 layers (Fig. 10d). Garnet-rich layer form boudins and the inter-boudins are mostly filled by quartz 328 or calcite-epidote veins (Fig. 10d). In these veins, quartz grains are also recrystallized by grain 329 boundary migration (Fig. 10d').

330 4.2. The transitional domain

331 This domain affects the upper Paleozoic series. It is distributed in a large region in the Chiroulet 332 dome that corresponds globally to the extension of the andalusite-bearing micaschists and is 333 localized within the Silurian black schists in the Lesponne dome. In the Chiroulet dome, the basal 334 limit of the transitional domain corresponds to the contact between the Silurian black schists 335 turned into paragneisses and the Lower Devonian meta-carbonates, both within the sillimanite 336 zone. The upper part of this domain can reach the Upper Devonian series and the Tourmalet shear 337 zone in the southern part of the massif (Figs 4 \& 6).

338 In the transitional domain, a high-strain fabric is marked by the total transposition of the bedding 339 and the development of a pervasive Si foliation. It is responsible for the boudinage of Devonian 
340 siliciclastic layers within the weak marbles. Li stretching lineation is defined by calcite, 341 pyroxene, or amphibole in marbles and sillimanite, andalusite, feldspar, or quartz in schists and 342 paragneisses.

343 Foliation trajectories show concentric patterns, surrounding domes' cores (Fig. 4b). These 344 foliation trajectories appear highly disturbed by polyharmonic $\mathrm{N} 100^{\circ}$ to $\mathrm{N} 130^{\circ}$ trending folds, 345 and specifically in the southern border of the Chiroulet dome (Fig. 4b). First-order folds are 346 kilometer-scale, tight to isoclinal (Fig. 6). They exhibit asymmetrical shapes and are all 347 overturned to the north (Figs $6 \& 8$ a). Similar folds may be recognized from meter to decameter 348 scale (Fig. 8). These numerous folds are responsible for multiple repetitions of the schists349 marbles intercalations, which could explain why the sillimanite-andalusite metamorphic zones 350 are thicker where these folds exist (Fig. 6).

351 Li show extremely variable trends, from roughly N-S to E-W but remain dominantly parallel to 352 the Li of the lower domain (Fig 5). On the field, the stretching lineation appears wrapped into 353 regional to local folds (Fig. 7f), suggesting passive reorientation by folding of the Si fabric. When 354 C' shears are associated with stretching, the relative sense of shear is also variable depending on 355 their location in regional folds (Figs. 4 b, 5 \& 6).

356 The intense folding of the Si foliation is associated with the development of an $\mathrm{N} 100-130^{\circ} \mathrm{E}$ axial 357 plane cleavage (Figs 4b \& 6). Within the hinges of folds, it forms a crenulation cleavage Ss (Fig. $3587 \mathrm{~g}$ ), which is marked by the crystallization of biotites in andalusite-sillimanite schists. Ss is E-W 359 striking and dips moderately to the south (Fig. 5). Localization of deformation in the flanks of 360 regional folds is recorded by the development of a mylonitic foliation mostly developed within 361 the marbles (Fig. 9a). Strain localization strongly reduced the thickness of marbles while tectonic 362 thickening is currently seen at the hinges (Figs $6 \& 8 \mathrm{a}$ ). Folded boudins are common (Fig. 8b, c, 
363 d), which suggests reworking of Si fabric. This mylonitic foliation Ss in marbles bears an N200 364 down-dip stretching or striae-lineation Ls (Fig. 5), defined by calcite or quartz ribbons (Fig. 7h).

365 Ls lineations are systematically associated with non-coaxial "top to the north" (i.e., reverse) or 366 "South side up" kinematics (Figs 6, 8a,e, \& 9a). North-directed thrusting is in accordance with 367 the regional asymmetry of the sheared folds. Similar deformation can be observed within Silurian 368 black schists at the top of the Lesponne gneiss dome, with strain localization of non-coaxial "top 369 to the north" (i.e., reverse) shearing associated with N-S stretching lineations (Fig. 9b). This 370 mylonitic contact has been locally reworked by post-Variscan faulting (see section 4.4 .2 below).

371 At the top of the transitional zone, the Si fabric appears mostly reworked by the steep and 372 penetrative Ss cleavage, with locally few preserved andalusite porphyroclasts. Stretching 373 lineations are still down-dip and kinematics associated with shear bands seems to be mostly 374 reverse (Figs. 4b \& 6).

375 The microstructural study within the limbs of the tight to isoclinal regional folds shows the 376 reworking of the high-temperature Si foliation by Ss mylonitic bands (Fig. 10e, e'). Core and 377 mantle textures characterized the Ss planes (Fig. 10e) with quartz 1 ribbons and a fine-grained 378 matrix of quartz 2 and muscovite forming the core and the mantle, respectively. Undulose 379 extinction and deformation bands in quartz ribbons, as well as the presence of fine quartz grains, 380 underline deformation at middle-temperature conditions probably around $400-450^{\circ} \mathrm{C}$, close to the 381 bulging/subgrain rotation transition defined by Stipp et al. (2002).

382 Near the boundary with the upper domain, chiastolitic-andalusites are partially retrogressed into 383 white micas while biotites are retrogressed into chlorites (Fig. 10f). Chlorite is also formed in 384 pressure shadows of andalusite porphyroclasts (Fig. 10f, f'). Andalusites show inclusions of an 385 early fabric that could be related to peak metamorphism (i.e., Si foliation) (Fig. 10f'). Quartz 
$387 \mu \mathrm{m}$ (Fig. 10f'), suggesting that deformation occurred at a temperature around $400-500^{\circ} \mathrm{C}$ (Stipp

388 et al., 2002). The retrogression of biotite, andalusite, and subgrain rotation recrystallization of 389 quartz suggest that reworking of Si by Ss is associated with regional cooling from amphibolite to 390 greenschist facies conditions. These observations are in accordance with estimates at $580^{\circ} \mathrm{C} / 2.3$ 391 kbar by Pouget (1989) for the peak of metamorphism associated with $\mathrm{Si}$ in the transitional 392 domain.

393 4.3. The upper domain

394 This upper domain belongs to the biotite and chlorite zones, where the original bedding of the 395 upper Paleozoic series is mainly preserved. These metasedimentary rocks are affected by tight E396 W to NW-SE trending folds and a steep axial plane cleavage (Fig. 6). Ss trajectories are molding 397 the gneiss domes, forming neutral points that are preserved at their western parts (Fig. 4b). 398 Locally, strain seems to be localized within Devonian marbles or Silurian black shales, where 399 bedding is transposed. These high-strain zones delineate the longitudinal regional shear zones 400 observed outside of the metamorphic aureoles of gneiss domes (Figs. 3 \& 4, e.g., the lateral 401 continuity of the Tourmalet shear zone). The stretching lineations Ls lying on the Ss fabrics have 402 an $\mathrm{N} 200^{\circ}$ trend, which is parallel to the Ls measurement within the transitional domain (Fig. 5).

403 Ls is mostly defined by quartz aggregates, calcite ribbons, or white micas flakes. Sense of shear 404 associated with shear planes depends on the dip direction of the shear planes and Ss, showing 405 systematically reverse kinematics (Figs. $5 \& 9 b$ ). The transition between the two directions of 406 thrusting seems to coincide with the Tourmalet shear zone, with the first occurrences of south407 verging thrusts and north-dipping Ss cleavage that are well known in the rest of the Axial Zone 408 (Figs $4 b$ \& 6, cross-section 1). 
409 The microstructural study of the Upper Carboniferous sandstones (Fig. 10a) evidences a well410 defined cleavage Ss, marked by dissolution joints (Fig. 10g). The matrix is made of very fine 411 grains of quartz, muscovite, and chlorite. Detrital quartz grains are poorly or not recrystallized, 412 showing undulose extinction while quartz from the matrix form aggregates of small crystals 413 showing homogeneous grain size probably developped by bulging recrystallization (Fig. 10g'). It

414 suggests that deformation occurred at temperatures below $400^{\circ} \mathrm{C}$ (Stipp et al., 2002), in 415 agreement with estimates from Pouget (1989) $\left(400-220^{\circ} \mathrm{C} / 2.3 \mathrm{kbar}\right)$ for the peak metamorphism. 416 The detrital quartz grains show symmetrical patterns, which indicates that deformation was 417 mainly coaxial.

4184.4 Early and late deformations:

419 4.4.1. Early (D1) deformation

420 In the studied area, occurrences of early deformation can be deduced at a map-scale in the upper 421 domain (Fig. 4). Indeed, moderate overprint of Ss on bedding allows preserving early D1 folds, 422 highlighted by intercalated limestones within Devonian schists (Fig. 4). These pre-Ss folds were 423 variably rotated, showing N-S to ENE-WSW trends outside and near gneiss dome, respectively. 424 Regarding the E-W cross-section (Fig. 6, cross-section 3), it appears that the dome shape of the 425 Lesponne is oblique to regional structures as the gneiss dome was emplaced into Cambro426 Ordovician rocks at the east and lower Devonian series at its western termination. This suggests 427 regional west-verging overturned or recumbent folds, like those observed in the western part of 428 the Axial Zone (Matte, 2002; Cochelin et al., 2017). In our studied area, the characteristics of the 429 D1 deformation event are difficult to determine at the scale of the outcrops and no proofs of the 430 existence of an early cleavage S1 have been underlined in the field.

This article is protected by copyright. All rights reserved. 
432 The magmatic rocks belonging to the lower domain were affected by localized low-grade (i.e. 433 chlorite stability field) ductile deformation (Fig. 4). It forms E-W to NW-SE meter-scale 434 mylonitic corridors that have been precisely mapped by Pouget (1984), showing an anastomosed 435 pattern. These corridors are steeply dipping and induce local perturbations of Si trajectories (Fig. 436 4b). As described by Pouget (1984), mylonites are marked by small porphyroclasts of quartz and 437 feldspars and by crystallization of white mica, chlorite, or epidote. The foliation mostly hosts a 438 shallow- dipping stretching lineation, defined by quartz aggregates. Steep C' shears show dextral 439 kinematics (Fig. 9c), which is consistent with the local inflection of Si trajectories (Fig. 4b). A 440 minor vertical component of movement is inferred because of shallowly plunging (i.e. with a 441 pitch between 5 to $45^{\circ}$ ) stretching lineations. The main low-grade dextral shear zone corresponds 442 to the Chiroulet shear zone, putting diatexites of the northern part of the Chiroulet massif in 443 contact with lower Devonian rocks or small sheets of Silurian black schists belonging to the 444 andalusite zone (Fig. 6). Following Pouget, (1984), these ductile shear zones could also affect the 445 upper domain laterally and are collinear to the regional Ss fabric. Therefore, these shear zones 446 could be Late Variscan in age, like those described in section 4.3.

447 In our studied area, late brittle deformation can be frequently observed and may be related to the 448 Alpine orogeny. The frequency of faults increases towards the north (i.e., towards the NPF, see 449 Fig. 4). They often reactivate Variscan structures such as Ss cleavage or Si foliation plane, with 450 down-dip striation covering the foliations planes with HT paragenesis (e.g., sillimanite, 451 andalusite, biotite, see Fig. 9d \& d'). When structural markers are present, such as post-Variscan 452 dykes (Fig. 9d), the faults show reverse sense of shear. Most of the time, Silurian black schists 453 localized faulting, especially around the Lesponne massif. Unfortunately, the amount of 
454 displacement along these faults during Alpine orogeny remains difficult to estimate, as the 455 current position of rocks results from both Variscan and Alpine tectonics. Furthermore, few 456 contacts such as the Oussouet-Cap de la Taoula thrust, seem to have experienced a more complex 457 history, including Post-Variscan normal faulting that could be Permian or Cretaceous in age. 458 Indeed, the reverse movement along the thrust was not sufficient to balance earlier normal 459 faulting (Fig. 6, compare cross-sections 4 \& 5). Despite reactivation of Variscan structures, the 460 impact of Alpine faulting remains limited as it doesn't disturb the metamorphic aureoles of gneiss 461 domes (e.g., the andalusite zone of the Lesponne dome stays centered on the sillimanite zone, 462 Fig. 4). Tilting to the north of Variscan structures can be observed at the vicinity of the NPF like 463 in the rest of the Axial Zone (see Cochelin et al., 2017) but this effect vanished 1-2 km south of 464 the fault (Ternet et al., 1996). The structural and metamorphic continuity and the absence of large 465 block rotation are thus well presented in our cross-sections (Fig. 6).

\section{5. Discussion}

\section{5.1. Gneiss dome formation by vertical strain partitioning}

468 Based on our structural and microstructural observations, and the integration of petrological and 469 geochronological data, we propose a scenario in which the Chiroulet-Lesponne gneiss domes 470 were formed in two steps during the D2 tectonic phase (Fig. 11). The two steps, that follow up an

471 early folding event in the upper crust (D1 phase Fig. 11a), have occurred in a continuum during 472 progressive cooling of the crust, subsequent to peak metamorphism and partial melting.

\section{5.1.1. Initiation of gneiss dome formation during longitudinal mid-crustal flow}

474 Deformation at peak metamorphic conditions is marked by strain partitioning between the upper 475 crust and the partially molten middle crust. The metasedimentary rocks of the upper crust were 
476 subjected to vertical stretching, folding, and formation of a steep axial plane cleavage. Syn-

477 kinematic plutons such as the Néouvielle pluton to the South of the Chiroulet dome were

478 emplaced in the upper crust and were affected by a weak deformation at sub-solidus to HT solid-

479 state conditions (Gleizes et al., 2001). This deformation, already described in the Axial Zone to

480 the East of the Chiroulet-Lesponne area, is compatible with N-S shortening-dominated

481 transpression and probably occurred from 310 to $300 \mathrm{Ma}$, during the main phase of pluton

482 emplacement.

483 The mid-lower crust recorded orogen-parallel flow (i.e. longitudinal) and formation of gneiss

484 domes (Fig. 11b). Gneiss dome formation suggests both gravitational instabilities linked to the

485 presence of partially molten rocks and strain localization that induced local upward flow.

486 Exhumation of gneiss core is marked by an isothermal decompression path in the migmatites, up

487 to ca. 3 kbar while the transitional domain recorded only a minor decrease of temperature (Fig.

488 11b). The impact of strain localization is identified by the contrasted evolution of the Chiroulet

489 and Lesponne domes. The Lesponne dome is in fact, only affected by lateral flow while the

490 Chiroulet dome is marked by the development of a transverse extensional shear zone on the

491 whole pile of Devonian metasedimentary rocks (Fig. 11b). This contrasted style of evolution is

492 correlated with various metamorphic conditions in the Devonian series of the two domes. This

493 suggests an upward propagation of the thermal anomaly in an already structured crust, inherited

494 from the D1 phase (Fig. 11a). The local weakening of Devonian marbles explains the formation

495 of a kilometer-scale decollement level above the migmatites of the nascent Chiroulet dome (Fig.

496 11a, b). Similarly, local orogen-normal extension assisted by strain localization within marbles

497 was also recognized in the Bossost dome located few kilometers to the east (Mezger \& Passchier

498 2003; Cochelin et al., 2017) or in the Canigou dome (Le Bayon \& Cochelin, 2020).

This article is protected by copyright. All rights reserved. 
499 This event recorded in the Chiroulet-Lesponne area expresses a turning-point of tectonic settings 500 and style of deformation. This turning-point has already been described in the Central and 501 Eastern domains of the Axial Zone synchronously with the widespread metamorphism and 502 magmatism taking place at ca. 310-290 Ma (e.g., Denèle et al., 2014; Lemirre et al., 2019, Fig. $5032 \mathrm{~b}$ ). The upward migration of the anatectic front progressively increased the geothermal gradient 504 in the above crust and led to a near isothermal gradient below (Lemirre, 2018; Lemirre et al., 505 2019). The persistence of this HT geothermal gradient during at least $10 \mathrm{Ma}$ (Lemirre et al., 506 2019, Fig. 2b) produced a long-lasting weakening of the crust.

507 5.1.2. Dome amplification and strain localization

508 Cross-cutting relationships of Ss and $\mathrm{Si}$ in the transitional domain, the late formation of north509 verging folds and thrusts surrounding the Chiroulet dome, and the formation of chlorite-bearing 510 shear zones that crosscut both the lower and upper crustal domains suggest a continuum of D2 511 deformation during progressive cooling of the crust, after the peak of the thermal anomaly (Fig. 512 11c). Progressive cooling of the crust is attested in a significant way by the reworking of the HT 513 Si fabrics by the MT Ss fabrics in the transitional zone. Crystallization of migmatites at ca. 290 $514 \mathrm{Ma}$ (Lemirre et al., 2019) at the top of the gneiss domes seems to constrain the ultimate age of 515 this event. We propose that this period is characterized by a progressive coupling between the 516 transitional domain at the top of the mid-lower crust and the upper crust implying competition 517 between orogen-parallel horizontal flow within the mid-lower crust and vertical stretching in the 518 upper crust. In this context of cooling, the still weak marbles and micaschists surrounding the 519 Chiroulet dome localized compressional deformation, forming north-verging folds and thrusts 520 (Figs. $6 \&$ 11c), and the domal shapes were amplified by large scale folding (Fig. 11c). In the 521 Lesponne dome, the Silurian black schists localized the deformation, preserving the dome from 
522 intense overprint by Ss structures (Fig. 11c). Progressive strain localization within steep

523 retrogressive shear zones at the limbs of gneiss domes allowed overturning the northern flank of

524 the Chiroulet dome (Fig. 11c). These late-Variscan shear zones are well-known in the Axial Zone

525 (e.g., Carreras, 2001, Druguet, 2001; Denèle et al., 2008; Cochelin et al., 2018b) and their

526 activation was recently constrained using $\mathrm{U} / \mathrm{Pb}$ dating on apatites at ca. $289 \mathrm{Ma}$ in the Central

527 Pyrenees (Poitrenaud, 2018; Poitrenaud et al., 2020).

528 5.2. Impact of strain partitioning on final strain patterns in orogens

530 Structural studies performed at the local scale in the Axial Zone led some authors to the 531 conclusion that only south-directed thrusts can be observed (e.g., García-Sansegundo et al., 532 2011). This interpretation is due to the truncation of the northern part of the Axial Zone by 533 Alpine structures oblique to Variscan ones, especially in its eastern half part (Fig. 3). Our study in 534 the Chiroulet-Lesponne area, where north-dipping thrusts are preserved, allows us to give a more 535 complete view of the Axial Zone. For these reasons we propose in our conceptual model (Fig. 536 12a) that the Variscan Axial Zone corresponds to a doubly verging accretionary domain (i.e., a 537 narrow orogenic belt) showing south verging thrusts in the southern part, a highly shortened 538 central domain with apparently coaxial deformation and north-verging thrusts on the northern 539 domain. The layered Variscan crust of the Pyrenees is thus characterized by opposite direction of 540 extrusion in response to $\mathrm{N}-\mathrm{S}$ horizontal shortening. While mid-lower crust laterally flows (lateral 541 escape), the thickening upper crust is affected by vertical (orogen-normal) extrusion (Fig. 12a). 542 The gneiss dome formation is linked to gravitational instabilities within the partially molten mid543 lower crust and strain localization that induced the activation of decollement levels, those latter 544 permitting partial decoupling between the two structural domains. The cooling of the crust at ca. 
545 300-290 Ma induced progressive coupling between the two structural domains, as highlighted by

546 the overprint of retrogressive reverse shear zones on high-grade fabrics within gneiss domes (Figs

$54711 \& 12 \mathrm{a})$. In our model, syn-convergence late-Carboniferous/early-Permian volcano-clastic

548 sediments (i.e., the "grey unit" and "transitional unit", see Pereira et al., 2014) are accumulated

549 into narrow longitudinal basins at the front of these steep thrusts (Fig. 12a) as suggested by recent

550 studies (e.g., Gretter et al., 2015; Lloret et al., 2018). Similar deposition of continental detrital

551 sediments at the front of Gzhelian thrusts was recorded in the Cantabrian Zone (e.g., Pérez-

552 Estaún et al., 1988; Alonso et al., 2009). The transition from deep-sea to intra-continental

553 sedimentation during the Carboniferous-Permian transition also suggests an increasing

554 topography. Thus, the short-lived lateral escape of the mid-lower crust may have not been

555 sufficient to balance overall thickening, which is typical of hot orogen deformation mode

556 (Cagnard et al., 2006; Gapais et al., 2009; Chardon et al., 2009; Bajolet et al., 2015).

557 In the North Pyrenean Massifs, the deformation appears more heterogeneous than in the Axial

558 Zone with evidence of longitudinal and transverse extension leading to significant crustal

559 thinning and exhumation of the lower crust by the activation of detachment faults (de Saint

560 Blanquat et al., 1990; de Saint Blanquat 1993; Saspiturry et al., 2019). To explain coeval

561 development of extensional structures in the NPM and contractional ones, mostly in the Axial

562 Zone, some advocated the existence of a Late-Variscan NPF separating these massifs (e.g.,

563 Arthaud \& Matte, 1975; Burg et al., 1994; Matte 2001; Carreras \& Druguet, 2014). Following

564 these authors, this supposed - but never observed - lithospheric structure would act as a dextral

565 mega shear zone or a transfer zone. Despite some uncertainties concerning the movement of the

566 Iberian plate at Mesozoic times, a large displacement along the NPF is now widely challenged for

567 the Alpine cycle (Jammes et al., 2009; Tugend et al., 2014, Canérot, 2016; Nirrengarten et al.,

This article is protected by copyright. All rights reserved. 
568 2018, Saspiturry et al., 2019, among others). Therefore, the NPM can be also reasonably 569 considered as the northern continuity of the Axial Zone at Late Variscan times and as a part of 570 the same late-Variscan transpressional tectonic system. In this context, considering that 571 transverse-dominated extension is recorded in the massifs marked by granulite facies 572 metamorphism (e.g., Agly, St-Barthélémy, Castillon, Ursuya, Fig. 3) and that the other massifs 573 recorded only amphibolite facies metamorphism, we suggest that transverse extension is driven 574 by local drastic rheological weakening of the crust. The contrasted structural patterns of the Axial 575 Zone and the North-Pyrenean massifs can be interpreted in terms of lateral strain partitioning due

576 to rheological heterogeneities within the abnormally hot crust during the late-Carboniferous to 577 early-Permian period.

578 5.2.2. Towards an integrated view of continental mass transfers in the southwestern 579 Variscan realm during Pangea amalgamation

580 In the Variscan domain of the Pyrenees, vertical strain partitioning occurred between 310 and 290

581 Ma (e.g., Denèle et al., 2014; Lemirre et al., 2019; Poitrenaud et al., 2020, Fig. 2b) synchronously 582 with large mass transfers that affected the ongoing dismantling Variscan belt under abnormally 583 hot thermal conditions (Fig. 12b). During this short period, folding of the whole Variscan belt led 584 ultimately to the closure of the Iberian-Armorican arc (Cochelin et al., 2017) and the formation of 585 the Cantabrian Orocline (e.g., Weil et al., 2010; Edel et al., 2018). Following the model of 586 formation of the Cantabrian Orocline by bucking of the lithosphere by Gutiérrez-Alonso et al., 587 (2004), shortened areas are supposed to be restricted to the inner parts of the arc (i.e., the 588 Cantabrian Zone) while the outer arc was subjected to widespread extension or wrenching. This 589 model explains lateral strain partitioning in NW Iberia but fails to explain why 590 compression/transpression occurred coevally in many places in the southern realm of the 
591 Variscan belt (see the introduction, Fig. 1). We propose that occurrences of transpressive 592 restraining bends in the southern Variscan belt at the late-Carboniferous to early-Permian period 593 reflect lateral strain partitioning and global reorganization of weak continental masses following 594 the ultimate accretion of Gondwana and Laurentia (Fig. 11b). Indeed, the persistence of high 595 geotherms in the Variscan belt (e.g., Fig. 2d, e) due to widespread partial melting and 596 accumulation of magmas in the middle crust after lithospheric delamination (Gutiérrez-Alonso et 597 al., 2004; Buzzi \& Gaggero, 2008; Laurent et al., 2017), as exemplified in most of the massifs 598 (Fig. 11b), favored global strain partitioning and triggered extreme mobility of the continental 599 crust. In such a model, three end-members are exemplified (Fig. 12), reflecting how strain can be 600 partitioned within the orogen: i) transpressive restraining bends (Variscan crust of the Pyrenees; 601 Fig. 12a) ii) domains affected by lateral escape combining wrenching and lateral extension 602 (Armorican Massif; Fig. 12c), and iii) those affected by transverse extension and gravitational 603 collapse, (East Massif Central; Fig. 12d). Coeval generation of folds and steep thrusts showing E$604 \mathrm{~W}$ trends in the Cantabrian Zone and the Axial Zone in response to N-S shortening (in present 605 coordinates) in Iberia implies that these two massifs could have formed a single and continuous 606 transpressional restraining bend. The Cantabrian-Axial Zone restraining bend could extend 607 eastward in a Gondwananan autochtonous domain that could correspond to the Mycenian domain 608 belonging to the Paleotethys realm (Stampfli et al., 2013) but such a hypothesis remains uncertain 609 because of the dismembering of the Iberian plate at Cenozoic times (Jolivet et al., 2020). At least 610 two other restraining bends were formed at the Carboniferous-Permian boundary, both 611 southwestward (the Alleghanian belt) and northeastward (Maures - Sardinia - Alpine External 612 Crystalline Massifs) (Fig. 12b). Therefore, it appears that shortening was not only accommodated 613 around bending oroclines as expected by Pastor-Galán et al., (2018) but at a larger scale, within 
614 the entire core of the Pangea supercontinent, coupling lateral extension, wrenching (Fig. 12c), 615 and the formation of highly shortened domains (Fig. 12a, b).

617 The Western arcuate Variscan belt has been compared to the Pamir West Himalayan syntax 618 (Matte, 1986; 1991). Since oroclinal bending appears to occur in a very different way as the 619 Indian Craton indenter have no equivalent in the weak late-Variscan domain squeezed between 620 the Laurussia and Gondwana cratonic land-masses (Fig. 13), these two belts are indeed 621 characterized by (i) development of crustal-scale strike-slip shear zones on the two branches of a 622 nascent syntax (e.g., Martínez Catalán, 2011; Zhang \& Sun, 2020), (ii) strain partitioning 623 processes leading to the exhumation of the deep crustal rock within extensional gneiss domes and 624 syn-convergence lateral and transverse escape of the weak mid-lower crust (Gapais et al., 1992; 625 Stephenson et al., 2001; Martínez Catalán et al., 2014; Gapais et al., 2015; Rutte et al., 2017), (iii) 626 accommodation of deformation over large distances (i.e. more than $600 \mathrm{~km}$ wide orogenic belts)

627 in a hot and weak orogenic lithosphere bounded by strong and colder cratonic lithospheres (Fig. 628 13).

629 However, the spatial distribution of domains affected by lateral escape, transverse extension, and 630 compression differs in many ways. Above all, it should be noticed that NNE-SSW convergence 631 at ca. 300-290 Ma in the Variscan belt is mostly due to an intracontinental collision (i.e., intra632 Pangea) that led to the formation of the Alleghanian belt (Michard et al., 2010; Edel et al., 2018; 633 Figs. $1 \& 12 \mathrm{~b}$ ), to the south-west of Western Europe. Thus, the structures that were formed at this 634 period result from the roughly northeastward propagation of stress within the initially NE-SW635 trending Variscan belt (Edel et al., 2018 and reference therein). Strain was thus accommodated 636 within a weak lithosphere by bending oroclines, lateral escape, and the formation of 
637 compressional/transpressional domains, which are distributed as restraining bends within the 638 whole southern part of the Variscan belt (Fig. 13a). On the contrary, the domains subjected to 639 compression appear as restricted to the edge of the orogen in the Himalayan-Tibet system (Fig. 640 13b). This difference may be explained by the fact that the Variscan belt was affected at ca. 310641300 Ma by orogen-parallel stress (Johnston et al., 2013, Edel et al., 2018) while the Himalayan642 Tibet system only recorded orogen-perpendicular stress (e.g., Bosboom, et al., 2014).

643 Syn-convergence gneiss dome formation by transverse extension is common in the Pamir syntax 644 (Fig. 13b), reflecting gravity-driven instabilities within the orogenic plateau (Rutte et al., 2017; 645 Worthington et al., 2020), which may be favored by decoupling between the lower and the upper 646 plate (Bajolet et al., 2015). On the contrary, gneiss dome formation by transverse extension at ca. $647300 \mathrm{Ma}$ remains rare in the Variscan belt, and occurrences are restricted to the Eastern Massif 648 Central, or, as described in this study, in few NPM. While those from the NPM are similar to the 649 gneiss domes that were developed in the Pamir syntax (i.e., syn-convergence), those from the 650 eastern Massif Central look different. Indeed, this massif only recorded N-S extension at 305-300 651 Ma, leading to the development of widespread sedimentary basins and locally extensional domes 652 (Fig. 13a) (Faure et al., 2009; Ducassou et al., 2019; Vanderhaeghe et al., 2020 and references 653 therein). This suggests a regional evolution with its own dynamics in response to an asymmetric 654 delamination process (Laurent et al., 2017). There, $\mathrm{N}-\mathrm{S}$ extension could also reflect the influence 655 of the Paleothethys realm to the south (Fig. 12a), which corresponds to a geodynamic free edge. 656 Indeed, roughly N-S extension was recorded within the Paleotethys realm since ca. 300-290 Ma 657 (e.g., Angì et al., 2010; Edel et al., 2014 and references therein). In our model of continuous 658 Cantabrian-Axial Zone restraining bend, longitudinal stretching of the weak lower crust by 659 eastward flow combined to the dextral component of shearing in the upper crust can also reflect 
660 the presence of this free edge to the east (Fig. 12a). Similarly, the propagation of the orogenic 661 front and the orogenic plateau to the west in the Himalayan-Tibet system is controlled by 662 boundary conditions. Indeed, the weak plateau involved in the Pamir syntax is extruded westward 663 as squeezed between the Tian Shan block and the Indian craton (Rutte et al., 2017; Worthington 664 et al., 2020).

665 To resume, despite both the Variscan and Himalaya-Tibet orogenic systems corresponds to weak 666 domains subjected to bending during ongoing convergence between strong cratonic blocks, they 667 document contrasted finite strain patterns. Specific strain pattern of bending orogenic system in 668 these two domains seems to be related at first-order to initial boundary conditions at the onset of 669 bending such as the direction of stress vs the trend of the earlier belt, the land-mass vs indenter 670 geometry of cratonic lithosphere, and the evolution of free-boundaries. Concerning the southern

671 Variscan belt, it appears that the marked change in the regional stress direction that has occurred 672 at about 310-300 Ma (Edel et al., 2018) was the expression of the self-subduction of the Pangea 673 that led ultimately to its break-up in Permian times (Gutiérrez-Alonso et al., 2008).

\section{Conclusion}

675 The structural patterns observed in the Chiroulet and the Lesponne gneiss domes illustrate how 676 strain was vertically partitioned within a weak layered crust subjected to shortening. This gave 677 rise to first-order structural constraints to retrieve the tectonic and rheological evolution of this 678 part of the Axial Zone in a context of widespread mass transfers and oroclinal bending in the core 679 of the Pangea.

680 Subjected to a thermal anomaly from the mantle, the lower crust of the Variscan belt was 681 progressively affected by partial melting at ca. 310 Ma. Upward propagation of HT 
682 metamorphism induced critical weakening of the crust that was subjected to N-S horizontal 683 shortening. The partially molten mid-lower crust was thus affected by horizontal longitudinal 684 here eastward - flowing while the upper crust was affected by folding and thickened. Migmatites 685 were partially exhumed due to gravity instabilities, leading to the formation of gneiss domes by 686 extension at their roof. This process was enhanced by the activation of a decollement level 687 located within the kilometer-thick upper Paleozoic marbles. The gneiss domes were then 688 amplified by folding while strain was localized within transpressional shear zones at ca. 290 Ma. 689 These shear zones show "top to the north" (i.e., reverse) kinematics, which is the opposite of 690 well-known transpressional shear zones from the rest of the Axial Zone.

691 By integrating these structural observations at a larger scale, we show that the Axial Zone forms a 692 symmetrical doubly verging accretionary domain where horizontal shortening is accommodated 693 by i) N-S compression yielding northward and southward extrusion of the thickening upper crust 694 by thrusting and ii) horizontal orogen-parallel extrusion of the partially molten lower crust, which 695 is typical of hot orogens. The gravity instabilities were enhanced within the granulitic crust in 696 several NPM, leading to local transverse extension. The evocation of a Late Variscan NPF as a 697 transfer zone or a lithospheric-scale dextral shear zone is not a necessary condition to explain the 698 differences between these neighboring Variscan massifs. As illustrated here, strain was 699 partitioned at the scale of the whole southern part of the Variscides. At the scale of the Variscan 700 belt, we propose that the nonrigid (i.e., weak) Pangea plate was affected by intense continental 701 mass reorganization at the Carboniferous-Permian boundary, leading to the formation of several 702 transpressional restraining bends, like the Cantabrian and Axial Zone bend, coevally with 703 oroclinal bending and continental block rotations. The differences in finite strain patterns 704 between the Variscan belt and other bent hot orogens result from contrasted initial and boundary 
705 conditions, such as the geometry of the strong vs weak lithosphere domains, the orientation of the

706 early belts with respect to the late-compressive stress, and the location of the free edges. In the

707 Variscan belt, the eastward escape of the crust from the Cantabrian-Axial Zone restraining bend

708 could be explained by the presence of a free edge to the east, corresponding to the Paleotethys

709 realm, in a context of Pangea self-subduction.

\section{Acknowledgment}

711 This work was supported by the BRGM through the Référentiel Géologique de la France

712 program (RGF). The redaction of this paper has been permitted thanks to the funding from the

713 Labex Volaire (ANR-10-LABX-100-01) based at Orléans University and BRGM. The newly

714 acquired structural data will be available on the RGF website (www.rgf.brgm.fr). We

715 acknowledge J. R. Martínez Catalán, C. Teyssier, G. Vignaroli and an anonymous reviewer for

716 helping to improve the manuscript, as well as F. Rossetti for the editorial handling.

\section{References}

718 Aguilar, C., Liesa, M., Castiñeiras, P., Navidad, M., 2014. Late Variscan metamorphic and 719 magmatic evolution in the eastern Pyrenees revealed by $\mathrm{U}-\mathrm{Pb}$ age zircon dating. Journal 720 of the Geological Society 171, 181-192. https://doi.org/10.1144/jgs2012-086

721 Aguilar, C., Liesa, M., Štípská, P., Schulmann, K., Muñoz, J.A., Casas, J.M., 2015. P-T-t-d

722 evolution of orogenic middle crust of the Roc de Frausa Massif (Eastern Pyrenees): a

723 result of horizontal crustal flow and Carboniferous doming? Journal of Metamorphic

724 Geology 33, 273-294. https://doi.org/10.1111/jmg.12120

725 Alonso, J.L., Marcos, A., Suárez, A., 2009. Paleogeographic inversion resulting from large out of 726 sequence breaching thrusts: The León Fault (Cantabrian Zone, NW Iberia). A new picture 727 of the external Variscan Thrust Belt in the Ibero-Armorican Arc. Geologica Acta 7, 451728 473. https://doi.org/10.1344/105.000001449

This article is protected by copyright. All rights reserved. 
729

730

731

732

733

734

735

736

737

738

739

740

741

742

743

744

745

746

747

748

749

750

751

752

753

754

755

756

757

758

759

Andrieux, P., 1982. Conditions de cristallisation et évolution paragénétique d'une charnockite hercynienne : le complexe granulitique d'Ansignan (Massif de l'Agly, PyrénéesOrientales). Bulletin de Minéralogie 105, 253-266. https://doi.org/10.3406/bulmi.1982.7613

Angì, G., Cirrincione, R., Fazio, E., Fiannacca, P., Ortolano, G., Pezzino, A., 2010. Metamorphic evolution of preserved Hercynian crustal section in the Serre Massif (Calabria-Peloritani Orogen, southern Italy). Lithos 115, 237-262. https://doi.org/10.1016/j.lithos.2009.12.008

Arthaud, F., Matte, Ph., 1975. Les decrochements tardi-hercyniens du sud-ouest de l'europe. Geometrie et essai de reconstitution des conditions de la deformation. Tectonophysics 25 , 139-171. https://doi.org/10.1016/0040-1951(75)90014-1

Authemayou, C., Le Gall, B., Caroff, M., \& Bussien Grosjean, D. (2019). Wrench-related dome formation and subsequent orogenic syntax bending in a hot orogen (Variscan IberoArmorican Arc, the Ouessant Island, France). Tectonics 38, 3563-3585. https://doi.org/10.1029/2018TC005189

Autran, A., Fonteilles, M., Guitard, G., 1970. Relations entre les intrusions de granitoides, l'anatexie et le metamorphisme regional considerees principalement du point de vue du role de l'eau; cas de la chaine hercynienne des Pyrenees orientales. Bulletin de La Société Géologique de France S7-XII, 673-731. https://doi.org/10.2113/gssgfbull.S7-XII.4.673

Ayora, C., Liesa, M., Delgado, J., 1993. Low-thermal-gradient Hercynian metamorphism in the eastern Pyrenees. Journal of Metamorphic Geology 11, 49-58. https://doi.org/10.1111/j.1525-1314.1993.tb00130.x

Bahamonde, J.R., Merino-Tomé, O.A., Heredia, N., 2007. A Pennsylvanian microbial boundstone-dominated carbonate shelf in a distal foreland margin (Picos de Europa Province, NW Spain). Sedimentary Geology 198, 167-193. https://doi.org/10.1016/j.sedgeo.2006.12.004

Bajolet, F., Chardon, D., Martinod, J., Gapais, D., Kermarrec, J.-J., 2015. Synconvergence flow inside and at the margin of orogenic plateaus: Lithospheric-scale experimental approach. Journal of Geophysical Research: Solid Earth 120, 2015 JB012110. https://doi.org/10.1002/2015JB012110

Bajolet, F., Replumaz, A., Lainé, R., 2013. Orocline and syntaxes formation during subduction and collision. Tectonics 32, 1529-1546. https://doi.org/10.1002/tect.20087

This article is protected by copyright. All rights reserved. 
Ballèvre, M., Catalán, J.R.M., López-Carmona, A., Pitra, P., Abati, J., Fernández, R.D., Ducassou, C., Arenas, R., Bosse, V., Castiñeiras, P., Fernández-Suárez, J., Barreiro, J.G., Paquette, J.-L., Peucat, J.-J., Poujol, M., Ruffet, G., Martínez, S.S., 2014. Correlation of the nappe stack in the Ibero-Armorican arc across the Bay of Biscay: a joint FrenchSpanish project. Geological Society, Special Publications 405, 77-113. https://doi.org/10.1144/SP405.13

Barbey, P., Villaros, A., Marignac, C., Montel, J.-M., 2015. Multiphase melting, magma emplacement and P-T-time path in late-collisional context: the Velay example (Massif Central, France). Bulletin de La Société Géologique de France 186, 93-116. https://doi.org/10.2113/gssgfbull.186.2-3.93

Beaumont, C., Jamieson, R.A., Nguyen, M.H., Lee, B., 2001. Himalayan tectonics explained by extrusion of a low-viscosity crustal channel coupled to focused surface denudation. Nature 414, 738-742. https://doi.org/10.1038/414738a

Blanco-Ferrera, S., Sanz-López, J., García-López, S., Bastida, F., 2017. Tectonothermal evolution of the northeastern Cantabrian zone (Spain). International Journal of Earth Sciences 106, 1539-1555. https://doi.org/10.1007/s00531-016-1365-5

Bosboom, R., Dupont-Nivet, G., Huang, W., Yang, W., Guo, Z., 2014. Oligocene clockwise rotations along the eastern Pamir: Tectonic and paleogeographic implications. Tectonics 33, 53-66. https://doi.org/10.1002/2013TC003388

Brun, J.-P., 2002. Deformation of the continental lithosphere: Insights from brittle-ductile models. Geological Society, Special Publications 200, 355-370. https://doi.org/10.1144/GSL.SP.2001.200.01.20

Burg, J.-P., Van Den Driessche, J., Brun, J.-P., 1994. Syn- to post-thickening extension in the Variscan Belt of Western Europe: Modes and structural consequences. Géologie de La France 33-51.

Buzzi, L., Gaggero, L., 2008. Petrogenesis of post - orogenic Lower Permian andesites in southern Europe: insights into the collapse of the Variscan range. Geodinamica Acta 21, 273-290. https://doi.org/10.3166/ga.21.273-290

Cagnard, F., Durrieu, N., Gapais, D., Brun, J.-P., Ehlers, C., 2006. Crustal thickening and lateral flow during compression of hot lithospheres, with particular reference to Precambrian times. Terra Nova 18, 72-78. https://doi.org/10.1111/j.1365-3121.2005.00665.x 
791

Cagnard, F., Gapais, D., Barbey, P., 2007. Collision tectonics involving juvenile crust: The example of the southern Finnish Svecofennides. Precambrian Research 154, 125-141. https://doi.org/10.1016/j.precamres.2006.12.011

Canérot, J., 2016. The Iberian Plate: myth or reality? Boletín Geológico y Minero 127, 563-574.

Carosi, R., Palmeri, R., 2002. Orogen-parallel tectonic transport in the Variscan belt of northeastern Sardinia (Italy): implications for the exhumation of medium-pressure metamorphic rocks. Geological Magazine 139, 497-511. https://doi.org/10.1017/S0016756802006763

Carreras, J., 2001. Zooming on Northern Cap de Creus shear zones. Journal of Structural Geology 23, 1457-1486. https://doi.org/10.1016/S0191-8141(01)00011-6

Carreras, J., Capella, I., 1994. Structures and Tectonics at Different Lithospheric Levels Tectonic levels in the Palaeozoic basement of the Pyrenees: a review and a new interpretation. Journal of Structural Geology 16, 1509-1524. https://doi.org/10.1016/01918141(94)90029-9

Carreras, J., Druguet, E., 2014. Framing the tectonic regime of the NE Iberian Variscan segment. Geological Society, Special Publications 405, 249-264. https://doi.org/10.1144/SP405.7

Carreras, J., Julivert, M., Santanach, P., 1980. Hercynian mylonite belts in the eastern Pyrenees: an example of shear zones associated with late folding. Journal of Structural Geology 2, $1 / 2,5-9$.

Casas, J.M., Fernández, O., Domingo, F., 2007. Carboniferous normal faults in the Eastern Pyrenees: evidences and age constrains of syn-orogenic Variscan extension. Geodinamica Acta 20, 385-392. https://doi.org/10.3166/ga.20.385-392

Casini, L., Cuccuru, S., Maino, M., Oggiano, G., Tiepolo, M., 2012. Emplacement of the Arzachena Pluton (Corsica-Sardinia Batholith) and the geodynamics of incoming Pangaea. Tectonophysics 544-545, 31-49. https://doi.org/10.1016/j.tecto.2012.03.028

Casini, L., Cuccuru, S., Puccini, A., Oggiano, G., Rossi, Ph., 2015. Evolution of the CorsicaSardinia Batholith and late-orogenic shearing of the Variscides. Tectonophysics 646, 6578. https://doi.org/10.1016/j.tecto.2015.01.017

Chardon, D., Gapais, D., Cagnard, F., 2009. Flow of ultra-hot orogens: A view from the Precambrian, clues for the Phanerozoic. Tectonophysics 477, 105-118. https://doi.org/10.1016/j.tecto.2009.03.008

This article is protected by copyright. All rights reserved. 
822 Chardon, D., Jayananda, M., Peucat, J.-J., 2011. Lateral constrictional flow of hot orogenic crust: 823 Insights from the Neoarchean of south India, geological and geophysical implications for orogenic plateaux. Geochemistry, Geophysics, Geosystems 12, Q02005. https://doi.org/10.1029/2010GC003398

826 Choulet, F., Faure, M., Fabbri, O., Monié, P., 2012. Relationships between magmatism and 827 extension along the Autun-La Serre fault system in the Variscan Belt of the eastern French Massif Central. International Journal of Earth Sciences 101, 393-413. https://doi.org/10.1007/s00531-011-0673-z

Clark, M.K., Royden, L.H., 2000. Topographic ooze: Building the eastern margin of Tibet by

Cochelin, B., Chardon, D., Denèle, Y., Gumiaux, C., Le Bayon, B., 2017. Vertical strain partitioning in hot Variscan crust: Syn-convergence escape of the Pyrenees in the IberianArmorican syntax. Bulletin de la Société géologique de France 188, 39.

837 Cochelin, B., Gumiaux, C., Chardon, D., Denèle, Y., Le Bayon, B., 2018a. Multi-scale strainfield 838 analysis using geostatistics: Investigating the rheological behavior of the hot Variscan 839 crust of the Pyrenees (Axial Zone). Journal of Structural Geology 116, 114-130. https://doi.org/10.1016/j.jsg.2018.07.024

841 Cochelin, B., Lemirre, B., Denèle, Y., Blanquat, M. de S., Lahfid, A., Duchêne, S., 2018b.

842 Structural inheritance in the Central Pyrenees: the Variscan to Alpine

843 tectonometamorphic evolution of the Axial Zone. Journal of the Geological Society 175, 844 336-351. https://doi.org/10.1144/jgs2017-066

845 Conand, C., Mouthereau, F., Ganne, J., Lin, A.T.-S., Lahfid, A., Daudet, M., Mesalles, L., 846 Giletycz, S., Bonzani, M., 2020. Strain Partitioning and Exhumation in Oblique Taiwan 847 Collision: Role of Rift Architecture and Plate Kinematics. Tectonics 39, e2019TC005798. 848 https://doi.org/10.1029/2019TC005798

849 Corsini, M., Rolland, Y., 2009. Late evolution of the southern European Variscan belt: 850 Exhumation of the lower crust in a context of oblique convergence. Comptes Rendus Geoscience, Mécanique de l'orogénie Varisque : Une Vision Moderne de Le Recherche 

Orogenic Research 341, 214-223. https://doi.org/10.1016/j.crte.2008.12.002

854 Davy, Ph., Cobbold, P.R., 1991. Experiments on shortening of a 4-layer model of the continental lithosphere. Tectonophysics 188, 1-25. https://doi.org/10.1016/0040-1951(91)90311-F

856 Debon, F., Enrique, P., Autran, A., 1996. Magmatisme hercynien. Synthèse Géologique et 857 Géophysique Des Pyrénées vol. 1, Orléans (France), BRGM-ITGE, 361-499.

858 Debon, F., Guitard, G., 1996. Carte de synthese metamorphisme et plutonisme hercyniens. Synthèse Géologique et Géophysique Des Pyrénées vol. 1, Orléans (France), BRGMITGE.

Delaperrière, E., Blanquat, M. de S., Brunel, M., Lancelot, J.R., 1994. Geochronologie U-Pb sur zircons et monazites dans le massif du Saint Barthelemy (Pyrenees, France); discussion des ages des evenements varisques et pre-varisques. Bulletin de La Societe Geologique de France 165, 101-112.

Delvolvé, J.-J., Perret, M.-F., 1989. Variation de l'âge des sediments calcaires et "Culm” carbonifère dans la chaine varisque du sud de la France : migration de l'orogenèse

872 Denèle, Y., Laumonier, B., Paquette, J.-L., Olivier, P., Gleizes, G., Barbey, P., 2014. Timing of granite emplacement, crustal flow and gneiss dome formation in the Variscan segment of the Pyrenees. Geological Society, Special Publications 405, 265-287.

876 Denèle, Y., Olivier, P., Gleizes, G., 2008. Progressive deformation of a zone of magma transfer 877 in a transpressional regime: The Variscan Mérens shear zone (Pyrenees, France). Journal of Structural Geology 30, 1138-1149. https://doi.org/10.1016/j.jsg.2008.05.006

879 Denèle, Y., Olivier, P., Gleizes, G., Barbey, P., 2009. Decoupling between the middle and upper crust during transpression-related lateral flow: Variscan evolution of the Aston gneiss dome (Pyrenees, France). Tectonophysics 477, 244-261. https://doi.org/10.1016/j.tecto.2009.04.033 
Denèle, Y., Olivier, P., Gleizes, G., Barbey, P., 2007. The Hospitalet gneiss dome (Pyrenees) revisited: lateral flow during Variscan transpression in the middle crust. Terra Nova 19, 445-453. https://doi.org/10.1111/j.1365-3121.2007.00770.x

Denèle, Y., Paquette, J.-L., Olivier, P., Barbey, P., 2012. Permian granites in the Pyrenees: the Aya pluton (Basque Country). Terra Nova 24, 105-113. https://doi.org/10.1111/j.13653121.2011.01043.x

de Hoÿm de Marien, L., Le Bayon, B., Pitra, P., Van Den Driessche, J., Poujol, M., Cagnard, F., 2019. Two-stage Variscan metamorphism in the Canigou massif: Evidence for crustal thickening in the Pyrenees. Journal of Metamorphic Geology 37, 863-888. https://doi.org/10.1111/jmg.12487

Díez Fernández, R., Martínez Catalán, J.R., Barreiro, J.G., Arenas, R., 2012. Extensional Flow during Gravitational Collapse: A Tool for Setting Plate Convergence (Padrón Migmatitic Dome, Variscan Belt, NW Iberia). The Journal of Geology 120, 83-103. https://doi.org/10.1086/662735

Díez Fernández, R., Pereira, M.F., 2017. Strike-slip shear zones of the Iberian Massif: Are they coeval? Lithosphere 9, 726-744. https://doi.org/10.1130/L648.1

Druguet, E., 2001. Development of high thermal gradients by coeval transpression and magmatism during the Variscan orogeny: insights from the Cap de Creus (Eastern Pyrenees). Tectonophysics 332, 275-293.

Druguet, E., Castro, A., Chichorro, M., Pereira, M.F., Fernández, C., 2014. Zircon geochronology of intrusive rocks from Cap de Creus, Eastern Pyrenees. Geological Magazine 151, 10951114. https://doi.org/10.1017/S0016756814000041

Ducassou, C., Mercuzot, M., Bourquin, S., Rossignol, C., Pellenard, P., Beccaletto, L., Poujol, M., Hallot, E., Pierson-Wickmann, A.C., Hue, C., Ravier, E., 2019. Sedimentology and $\mathrm{U}-\mathrm{Pb}$ dating of Carboniferous to Permian continental series of the northern Massif Central (France): Local palaeogeographic evolution and larger scale correlations. Palaeogeography, Palaeoclimatology, Palaeoecology 533, 109228. https://doi.org/10.1016/j.palaeo.2019.06.001

Echtler, H., Malavieille, J., 1990. Extensional tectonics, basement uplift and Stephano-Permian collapse basin in a late Variscan metamorphic core complex (Montagne Noire, Southern Massif Central). Tectonophysics 177, 125-138. 
914 Edel, J.-B., Casini, L., Oggiano, G., Rossi, P., Schulmann, K., 2014. Early Permian 90

915 clockwise rotation of the Maures-Estérel-Corsica-Sardinia block confirmed by new

916 palaeomagnetic data and followed by a Triassic $60^{\circ}$ clockwise rotation. Geological

917 Society, Special Publications 405, 333-361. https://doi.org/10.1144/SP405.10

918 Edel, J.B., Schulmann, K., Lexa, O., Lardeaux, J.M., 2018. Late Palaeozoic palaeomagnetic and

919 tectonic constraints for amalgamation of Pangea supercontinent in the European Variscan

920 belt. Earth-Science Reviews 177, 589-612.

921 https://doi.org/10.1016/j.earscirev.2017.12.007

922 Escuder Viruete, J., Hernáiz Huerta, P.P., Valverde-Vaquero, P., Rodríguez Fernández, R.,

923 Dunning, G., 1998. Variscan syncollisional extension in the Iberian Massif: structural,

924 metamorphic and geochronological evidence from the Somosierra sector of the Sierra de

925 Guadarrama (Central Iberian Zone, Spain). Tectonophysics 290, 87-109.

926 Esteban, J.J., Aranguren, A., Cuevas, J., Hilario, A., Tubía, J.M., Larionov, A., Sergeev, S., 2015.

927 Is there a time lag between the metamorphism and emplacement of plutons in the Axial

928 Zone of the Pyrenees? Geological Magazine 152, 935-941.

929 https://doi.org/10.1017/S001675681500014X

930 Evans, N.G., 1993. Deformation during the emplacement of the Maladeta granodiorite, Spanish 931 Pyrenees. $\mathrm{PhD}$ thesis, University of Leeds.

932 Evans, N.G., Gleizes, G., Leblanc, D., Bouchez, J.L., 1998. Syntectonic emplacement of the

933 Maladeta granite (Pyrenees) deduced from relationships between Hercynian deformation

934 and contact metamorphism. Journal of the Geological Society 155, 209-216.

935 https://doi.org/10.1144/gsjgs.155.1.0209

936 Faure, M., Lardeaux, J.-M., Ledru, P., 2009. A review of the pre-Permian geology of the

937 Variscan French Massif Central. Comptes Rendus Geoscience, 341, 202-213.

938 https://doi.org/10.1016/j.crte.2008.12.001

939 Faure, M., Prost, A.E., Lasne, E., 1990. Déformation ductile extensive d'âge namuro-westphalien

940 dans le plateau d'Aigurande, Massif central français. Bullutin de la Société Géologique de 941 France 8, 189-197.

942 Fossen, H., Cavalcante, G.C.G., 2017. Shear zones - A review. Earth-Science Reviews 171, 434943 455. http://dx.doi.org/10.1016/j.earscirev.2017.05.002

This article is protected by copyright. All rights reserved. 
944

Franke, W., 2014. Topography of the Variscan orogen in Europe: failed-not collapsed. International Journal of Earth Sciences 103, 1471-1499. https://doi.org/10.1007/s00531014-1014-9

Fréville, K., Trap, P., Faure, M., Melleton, J., Li, X.-H., Lin, W., Blein, O., Bruguier, O., Poujol, M., 2018. Structural, metamorphic and geochronological insights on the Variscan evolution of the Alpine basement in the Belledonne Massif (France). Tectonophysics 726, 14-42. https://doi.org/10.1016/j.tecto.2018.01.017

Gapais, D., 1989. Shear structures within deformed granites: Mechanical and thermal indicators. Geology 17, 1144-1147. https://doi.org/10.1130/00917613(1989)017<1144:SSWDGM>2.3.CO;2

Gapais, D., Brun, J.-P., Gumiaux, C., Cagnard, F., Ruffet, G., Le Carlier De Veslud, C., 2015. Extensional tectonics in the Hercynian Armorican belt (France). An overview. Bulletin de La Société Géologique de France 186, 117-129. https://doi.org/10.2113/gssgfbull.186.23.117

Gapais, D., Cagnard, F., Gueydan, F., Barbey, P., Ballèvre, M., 2009. Mountain building and exhumation processes through time: inferences from nature and models. Terra Nova 21, 188-194. https://doi.org/10.1111/j.1365-3121.2009.00873.x

Gapais, D., Pêcher, A., Gilbert, E., Ballèvre, M., 1992. Synconvergence spreading of the higher Himalaya crystalline in Ladakh. Tectonics 11, 1045-1056. https://doi.org/10.1029/92TC00819

Gapais, D., Potrel, A., Machado, N., Hallot, E., 2005. Kinematics of long-lasting Paleoproterozoic transpression within the Thompson Nickel Belt, Manitoba, Canada. Tectonics 24. https://doi.org/10.1029/2004TC001700

García-López, S., Voldman, G.G., Bastida, F., Aller, J., 2018. Tectonothermal analysis of a major unit of the Cantabrian Zone: the Ponga unit (Variscan belt, NW Spain). International Journal of Earth Sciences 107, 2727-2740. https://doi.org/10.1007/s00531-018-1623-9

García-Sansegundo, J., Poblet, J., Alonso, J.L., Clariana, P., 2011. Hinterland-foreland zonation of the Variscan orogen in the Central Pyrenees: comparison with the northern part of the Iberian Variscan Massif. Geological Society, Special Publications 349, 169-184. https://doi.org/10.1144/SP349.9 
974 Genna, A., Roig, J.-Y., Debriette, J.-P., Bouchot, V., 1998. Le bassin houiller d'Argentat (Massif 975 central français), conséquence topographique d'un plissement de son substratum varisque. 976 C. R. Acad. Sci. Paris 327, 279-284.

977 Giró, E., Alías López, G., 2007. Evolución metamórfica de las kinzigitas en facies granulita del 978 macizo del Aglí. Geogaceta 41, 95-98.

979 Gleizes, G., Crevon, G., Asrat, A., Barbey, P., 2006. Structure, age and mode of emplacement of 980 the Hercynian Bordères-Louron pluton (Central Pyrenees, France). International Journal of Earth Sciences 95, 1039-1052. https://doi.org/10.1007/s00531-006-0088-4

Gleizes, G., Leblanc, D., Bouchez, J.L., 1998. The main phase of the Hercynian orogeny in the Pyrenees is a dextral transpression. Geological Society, Special Publications 135, $267-$ 273. https://doi.org/10.1144/GSL.SP.1998.135.01.17

985

986

987

988

989

990

991

992

993

Gleizes, G., Leblanc, D., Olivier, P., Bouchez, J., 2001. Strain partitioning in a pluton during emplacement in transpressional regime: the example of the Néouvielle granite (Pyrenees). International Journal of Earth Sciences 90, 325-340. https://doi.org/10.1007/s005310000144

Gretter, N., Ronchi, A., López-Gómez, J., Arche, A., De la Horra, R., Barrenechea, J., Lago, M., 2015. The Late Palaeozoic-Early Mesozoic from the Catalan Pyrenees (Spain): 60 Myr of environmental evolution in the frame of the western peri-Tethyan palaeogeography. Earth-Science Reviews 150, 679-708. https://doi.org/10.1016/j.earscirev.2015.09.001

Guerrot, C., 2001. Résultats de datation U-Pb par dissolution sur zircons pour l'échantillon SRYN37-1, Maroc. Rapport technique BRGM No. ANA H4028A.

Guitard, G., Vielzeuf, D., Martinez, F., 1996. Métamorphisme hercynien. Synthèse Géologique et Géophysique Des Pyrénées vol. 1, Orléans (France), Edition BRGM - ITGE, 501-584.

Gutiérrez-Alonso, G., Fernández-Suárez, J., Weil, A.B., 2004. Orocline triggered lithospheric delamination. Geological Society of America Special Papers 383, 121-130. https://doi.org/10.1130/0-8137-2383-3(2004)383[121:OTLD]2.0.CO;2

Gutiérrez-Alonso, G., Fernández-Suárez, J., Weil, A.B., Brendan Murphy, J., Damian Nance, R., Corfú, F., Johnston, S.T., 2008. Self-subduction of the Pangaean global plate. Nature Geoscience 1, 549-553. https://doi.org/10.1038/ngeo250

This article is protected by copyright. All rights reserved. 
1003 Gutiérrez-Alonso, G., Johnston, S.T., Weil, A.B., Pastor-Galán, D., Fernández-Suárez, 2012.

1004 Buckling an orogen: The Cantabrian Orocline. GSA Today 22, 4-9.

1005 https://doi.org/10.1130/GSATG141A.1

1006 Hart, N.R., Stockli, D.F., Hayman, N.W., 2016. Provenance evolution during progressive rifting 1007 and hyperextension using bedrock and detrital zircon U-Pb geochronology, Mauléon

1008 Basin, western Pyrenees. Geosphere 12, 1166-1186. https://doi.org/10.1130/GES01273.1

1009 Hernández Enrile, J.L., 1991. Extensional tectonics of the toledo ductile-brittle shear zone,

1010

1011

1012

1013

1014

1015

1016

1017

1018

1019

1020

1021

1022

1023

1024

1025

1026

1027

1028

1029

1030

1031

1032

1033 central Iberian Massif. Tectonophysics 191, 311-324. https://doi.org/10.1016/00401951(91)90064-Y

Jamieson, R.A., Beaumont, C., 2011. Coeval thrusting and extension during lower crustal ductile flow - implications for exhumation of high-grade metamorphic rocks. Journal of Metamorphic Geology 29, 33-51. https://doi.org/10.1111/j.1525-1314.2010.00908.x

Jammes, S., Manatschal, G., Lavier, L., Masini, E., 2009. Tectonosedimentary evolution related to extreme crustal thinning ahead of a propagating ocean: Example of the western Pyrenees. Tectonics 28, TC4012. https://doi.org/10.1029/2008TC002406

Johnston, S.T., Weil, A.B., Gutiérrez-Alonso, G., 2013. Oroclines: Thick and thin. GSA Bulletin 125, 643-663. https://doi.org/10.1130/B30765.1

Jolivet, L., Romagny, A., Gorini, C., Maillard, A., Thinon, I., Couëffé, R., Ducoux, M., Séranne, M., 2020. Fast dismantling of a mountain belt by mantle flow: Late-orogenic evolution of Pyrenees and Liguro-Provençal rifting. Tectonophysics 776, 228312. https://doi.org/10.1016/j.tecto.2019.228312

Kilzi, M.A., 2014. Etude pétro-géochimique des formations mafiques et ultramafiques associées aux formations granulitiques, métamorphiques et anatectiques des Pyrénées hercyniennes (massif du Castillon et massif de Gavarnie). PhD thesis, Université Paul Sabatier, Toulouse, France.

Kilzi, M.A., Grégoire, M., Bosse, V., Benoît, M., Driouch, Y., de Saint Blanquat, M., Debat, P., 2016. Geochemistry and zircon U-Pb geochronology of the ultramafic and mafic rocks emplaced within the anatectic series of the Variscan Pyrenees: The example of the Gavarnie-Heas dome (France). Comptes Rendus Geoscience 348, 107-115. https://doi.org/10.1016/j.crte.2015.06.014

Kretz, R., 1983. Symbols for rock-forming minerals. American Mineralogist 68, 277-279.

This article is protected by copyright. All rights reserved. 
1034 Krýza, O., Závada, P., Lexa, O., 2019. Advanced strain and mass transfer analysis in crustal-scale oroclinal buckling and detachment folding analogue models. Tectonophysics 764, 88109. https://doi.org/10.1016/j.tecto.2019.05.001

Kunz, B.E., Manzotti, P., von Niederhäusern, B., Engi, M., Darling, J.R., Giuntoli, F., Lanari, P., 2018. Permian high-temperature metamorphism in the Western Alps (NW Italy). International Journal of Earth Sciences 107, 203-229. https://doi.org/10.1007/s00531017-1485-6

Laurent, O., Couzinié, S., Zeh, A., Vanderhaeghe, O., Moyen, J.-F., Villaros, A., Gardien, V., Chelle-Michou, C., 2017. Protracted, coeval crust and mantle melting during Variscan late-orogenic evolution: $\mathrm{U}-\mathrm{Pb}$ dating in the eastern French Massif Central. International Journal of Earth Sciences 106, 421-451. https://doi.org/10.1007/s00531-016-1434-9

Le Bayon, B., Cochelin, B., 2020. Anatomy of an extensional shear zone leading to the exhumation of the middle crust within the Canigou dome (Eastern Pyrenees, Axial Zone). Journal of Structural Geology 141, 104200. https://doi.org/10.1016/j.jsg.2020.104200

Leblanc, D., Gleizes, G., Roux, L., Bouchez, J.L., 1996. Variscan dextral transpression in the French Pyrenees: new data from the Pic des Trois-Seigneurs granodiorite and its country rocks. Tectonophysics 261, 331-345. https://doi.org/10.1016/0040-1951(95)00174-3

Ledru, P., Courrioux, G., Dallain, C., Lardeaux, J.M., Montel, J.M., Vanderhaeghe, O., Vitel, G., 1053 2001. The Velay dome (French Massif Central): melt generation and granite emplacement

1055 Lemirre, B., 2018. Origine et développement de la thermicité dans les Pyrénées varisques. PhD 1056 thesis. Université Paul Sabatier, Toulouse, France.

1057 Lemirre, B., Cochelin, B., Duchene, S., de Saint Blanquat, M., Poujol, M., 2019. Origin and 1058 duration of late orogenic magmatism in the foreland of the Variscan belt (Lesponne Chiroulet — Neouvielle area, French Pyrenees). Lithos 336-337, 183-201.

1061 Lloret, J., Ronchi, A., López-Gómez, J., Gretter, N., De la Horra, R., Barrenechea, J.F., Arche, 1062 1063 A., 2018. Syn-tectonic sedimentary evolution of the continental late Palaeozoic-early Mesozoic Erill Castell-Estac Basin and its significance in the development of the central 

https://doi.org/10.1016/j.sedgeo.2018.07.014

1066 Lopez-Sanchez, M.A., García-Sansegundo, J., Martínez, F.J., 2018. The significance of early Permian and early Carboniferous U-Pb zircon ages in the Bossòst and Lys-Caillaouas granitoids (Pyrenean Axial Zone). Geological Journal 54, 1-16. https://doi.org/10.1002/gj.3283

1070 Lotout, C., Poujol, M., Pitra, P., Anczkiewicz, R., Van Den Driessche, J., 2020. From Burial to Exhumation: Emplacement and Metamorphism of Mafic Eclogitic Terranes Constrained Through Multimethod Petrochronology, Case Study from the Lévézou Massif (French Massif Central, Variscan Belt). Journal of Petrology 61. https://doi.org/10.1093/petrology/egaa046

Martínez Catalán, J.R., 2011. Are the oroclines of the Variscan belt related to late Variscan strike-slip tectonics? Terra Nova 23, 241-247. https://doi.org/10.1111/j.1365-

1078 Martínez Catalán, J.R., Arenas, R., García, F.D., Cuadra, P.G., Gómez-Barreiro, J., Abati, J., 1079 Castiñeiras, P., Fernández-Suárez, J., Martínez, S.S., Andonaegui, P., Clavijo, E.G., Montes, A.D., Pascual, F.J.R., Aguado, B.V., 2007. Space and time in the tectonic evolution of the northwestern Iberian Massif: Implications for the Variscan belt. In: 4-D framework of continental crust (R.D. Hatcher Jr., M.P. Carlson, J.H. McBride and J.R. Martínez Catalán, Eds.). Geological Society of America Memoirs 200, 403-423.

1085 Martínez Catalán, J.R., Pascual, F.J.R., Montes, A.D., Fernández, R.D., Barreiro, J.G., Silva, 1086 Í.D.D., Clavijo, E.G., Ayarza, P., Alcock, J.E. (2014). The late Variscan HT/LP metamorphic event in NW and Central Iberia: relationships to crustal thickening, extension, orocline development and crustal evolution. Geological Society, Special

1090 Matte, P., 1986. Tectonics and plate tectonics model for the Variscan belt of Europe. 1091 Tectonophysics 126, 329-374.

1092 Matte, P., 1991. Accretionary history and crustal evolution of the Variscan belt in Western 1093 Europe. Tectonophysics 196, 309-337. https://doi.org/10.1016/0040-1951(91)90328-P 
1094 Matte, P., 2001. The Variscan collage and orogeny (480-290 Ma) and the tectonic definition of 1095 the Armorica microplate: a review. Terra Nova 13, 122-128.

1096 https://doi.org/10.1046/j.1365-3121.2001.00327.x

1097 Matte, P., 2002. Les plis hercyniens kilométriques couchés vers l'ouest-sud-ouest dans la région 1098 du pic du Midi d'Ossau-col du Somport (zone axiale des Pyrénées occidentales).

1099 Comptes Rendus Geoscience 334, 773-779.

1100 Maurel, O., Respaut, J.-P., Monié, P., Arnaud, N., Brunel, M., 2004. U-Pb emplacement and

1101

1102

1103

1104

1105

1106

1107

1108

1109

1110

1111

1112

1113

1114

1115

1116

1117

1118

1119

1120

1121

1122

1123

1124 40Ar/39Ar cooling ages of the eastern Mont-Louis granite massif (Eastern Pyrenees, France). Comptes Rendus Geoscience 336, 1091-1098. https://doi.org/10.1016/j.crte.2004.04.005

Mendia, M.S., Ibarguchi, J.I.G., 1991. High-grade metamorphic rocks and peridotites along the Leiza Fault (Western Pyrenees, Spain). Geologische Rundschau 80, 93-107. https://doi.org/10.1007/BF01828769

Merino-Tomé, O.A., Bahamonde, J.R., Colmenero, J.R., Heredia, N., Villa, E., Farias, P., 2009. Emplacement of the Cuera and Picos de Europa imbricate system at the core of the Iberian-Armorican arc (Cantabrian zone, north Spain): New precisions concerning the timing of arc closure. Geological Society of America Bulletin 121, 729-751. https://doi.org/10.1130/B26366.1

Mezger, J.E., 2009. Transpressional tectonic setting during the main Variscan deformation: evidence from four structural levels in the Bossòst and Aston-Hospitalet mantled gneiss domes, central Axial Zone, Pyrenees. Bulletin de La Societe Geologique de France 180, 199-207. https://doi.org/10.2113/gssgfbull.180.3.199

Mezger, J.E., Gerdes, A., 2016. Early Variscan (Visean) granites in the core of central Pyrenean gneiss domes: implications from laser ablation $\mathrm{U}-\mathrm{Pb}$ and $\mathrm{Th}-\mathrm{Pb}$ studies. Gondwana Research 29, 181-198. https://doi.org/10.1016/j.gr.2014.11.010

Mezger, J.E., Passchier, C.W., 2003. Polymetamorphism and ductile deformation of staurolitecordierite schist of the Bossòst dome: indication for Variscan extension in the Axial Zone of the central Pyrenees. Geological Magazine 140, 595-612. https://doi.org/10.1017/S0016756803008112

Mezger, J.E., Passchier, C.W., Régnier, J.-L., 2004. Metastable staurolite-cordierite assemblage of the Bossòst dome: Late Variscan decompression and polyphase metamorphism in the 
1125

1126

1127

1128

1129

1130

1131

1132

1133

1134

1135

1136

1137

1138

1139

1140

1141

1142

1143

1144

1145

1146

1147

1148

1149

1150

1151

1152

1153

1154

Axial Zone of the central Pyrenees. Comptes Rendus Geoscience 336, 827-837. https://doi.org/10.1016/j.crte.2003.12.024

Mezger, J.E., Régnier, J.-L., 2016. Stable staurolite-cordierite assemblages in K-poor metapelitic schists in Aston and Hospitalet gneiss domes of the central Pyrenees (France, Andorra). Journal of Metamorphic Geology 34, 167-190. https://doi.org/10.1111/jmg.12177

Michard, A., Soulaimani, A., Hoepffner, C., Ouanaimi, H., Baidder, L., Rjimati, E.C., Saddiqi, O., 2010. The South-Western Branch of the Variscan Belt: Evidence from Morocco. Tectonophysics 492, 1-24. https://doi.org/10.1016/j.tecto.2010.05.021

Moyen, J.-F., Laurent, O., Chelle-Michou, C., Couzinié, S., Vanderhaeghe, O., Zeh, A., Villaros, A., Gardien, V., 2017. Collision vs. subduction-related magmatism: Two contrasting ways of granite formation and implications for crustal growth. Lithos 277, 154-177. https://doi.org/10.1016/j.lithos.2016.09.018

Nirrengarten, M., Manatschal, G., Tugend, J., Kusznir, N., Sauter, D., 2018. Kinematic Evolution of the Southern North Atlantic: Implications for the Formation of Hyperextended Rift Systems. Tectonics 37, 89-118. https://doi.org/10.1002/2017TC004495

Olivier, P., Gleizes, G., Paquette, J.L., 2004. Gneiss domes and granite emplacement in an obliquely convergent regime: New interpretation of the Variscan Agly Massif (Eastern Pyrenees, France). Geological Society of America Special Papers 380, 229-242. https://doi.org/10.1130/0-8137-2380-9.229

Olivier, P., Gleizes, G., Paquette, J.-L., Muñóz Sáez, C., 2008. Structure and U-Pb dating of the Saint-Arnac pluton and the Ansignan charnockite (Agly Massif): a cross-section from the upper to the middle crust of the Variscan Eastern Pyrenees. Journal of the Geological Society $165,141-152$.

Paquette, J.-L., Gleizes, G., Leblanc, D., Bouchez, J.-L., 1997. Le granite de Bassiès (Pyrénées) : un pluton syntectonique d'âge Westphalien. Géochronologie U-Pb sur zircons. Comptes rendus de l'Académie des sciences S2, 324, 387-392.

Pastor-Galán, D., Martín-Merino, G., Corrochano, D., 2014. Timing and structural evolution in the limb of an orocline: The Pisuerga-Carrión Unit (southern limb of the Cantabrian Orocline, NW Spain). Tectonophysics 622, 110-121. https://doi.org/10.1016/j.tecto.2014.03.004

This article is protected by copyright. All rights reserved. 
1155

1156

1157

1158

1159

1160

1161

1162

1163

1164

1165

1166

1167

1168

1169

1170

1171

1172

1173

1174

1175

1176

1177

1178

1179

1180

1181

1182

1183

1184

Pastor-Galán, D., Pueyo, E.L., Diederen, M., García-Lasanta, C., Langereis, C.G., 2018. Late Paleozoic Iberian Orocline(s) and the Missing Shortening in the Core of Pangea. Paleomagnetism From the Iberian Range. Tectonics 37, 3877-3892. https://doi.org/10.1029/2018TC004978

Pereira, M.F., Castro, A., Chichorro, M., Fernández, C., Díaz-Alvarado, J., Martí, J., Rodríguez, C., 2014. Chronological link between deep-seated processes in magma chambers and eruptions: Permo-Carboniferous magmatism in the core of Pangaea (Southern Pyrenees). Gondwana Research 25, 290-308. https://doi.org/10.1016/j.gr.2013.03.009

Pérez-Estaún, A., Bastida, F., Alonso, J.L., Marquínez, J., Aller, J., Alvarez-Marrón, J., Marcos, A., Pulgar, J.A., 1988. A thin-skinned tectonics model for an arcuate fold and thrust belt: The Cantabrian Zone (Variscan Ibero-Armorican Arc). Tectonics 7, 517-537. https://doi.org/10.1029/TC007i003p00517

Petri, B., Mohn, G., Skrzypek, E., Mateeva, T., Galster, F., Manatschal, G., 2017. U-Pb geochronology of the Sondalo gabbroic complex (Central Alps) and its position within the Permian post-Variscan extension. International Journal of Earth Sciences 106, 28732893. https://doi.org/10.1007/s00531-017-1465-X

Pin, C., Vielzeuf, D., 1983. Granulites and related rocks in Variscan median Europe: A dualistic interpretation. Tectonophysics 93, 47-74. https://doi.org/10.1016/0040-1951(83)90233-0

Poitrenaud, T., 2018. Le gisement périgranitique à tungstène et or de Salau (Pyrénées, France), histoire polyphasée d'un système minéralisé tardi-varisque. $\mathrm{PhD}$ thesis, Université d'Orléans, France.

Poitrenaud, T., Poujol, M., Augier, R., Marcoux, E., 2020. The polyphase evolution of a late Variscan W/Au deposit (Salau, French Pyrenees): insights from REE and U/Pb LA-ICPMS analyses. Mineralium Deposita 55, 1127-1147. https://doi.org/10.1007/s00126-01900923-2

Pouget, P., 1984. Géologie de la région de Lesponne (Hautes-Pyrénées) = Geology of Lesponne area, Hautes-Pyrénées. PhD thesis, Univ. Paul Sabatier, Toulouse, France.

Pouget, P., 1987. Le massif granitique de Lesponne (Hautes Pyrénées): Un exemple de massif plutonique hercynien à mise en place diapirique syncinématique. Geologische Rundschau 76, 187-199. https://doi.org/10.1007/BF01820582

This article is protected by copyright. All rights reserved. 
1185 Pouget, P., 1989. Évolution géodynamique hercynienne des Pyrénées centrales. Contraintes structurales, métamorphiques, magmatiques et sédimentologiques. Thesis, Univ. Paul Sabatier, Toulouse, France.

1188 Pouget, P.P., Lamouroux, C., Dahmani, A., Debat, P., Driouch, Y., Mercier, A., Soula, J.C., Vezat, R., 1989. Typologie et mode de mise en place des roches magmatiques dans les Pyrénées hercyniennes. Geologische Rundschau 78, 537-554.

1191 https://doi.org/10.1007/BF01776190

1192 Roberts, M.P., Pin, C., Clemens, J.D., Paquette, J.-L., 2000. Petrogenesis of Mafic to Felsic 1193 Plutonic Rock Associations: the Calc-alkaline Quérigut Complex, French Pyrenees. Journal of Petrology 41, 809-844. https://doi.org/10.1093/petrology/41.6.809

Rolin, P., Colchen, M., 2001. Les cisaillements hercyniens de la Vendée au Limousin. Géologie 1196 de La France 1-2, 87-116.

1197 Rolland, Y., Corsini, M., Demoux, A., 2009. Metamorphic and structural evolution of the 1198 Maures-Tanneron massif (SE Variscan chain): evidence of doming along a transpressional margin. Bulletin de La Société Géologique de France 180, 217-230. https://doi.org/10.2113/gssgfbull.180.3.217

1201 Rolland, Y., Mahéo, G., Guillot, S., Pecher, A., 2001. Tectono-metamorphic evolution of the Karakorum Metamorphic complex (Dassu-Askole area, NE Pakistan): exhumation of mid-crustal HT-MP gneisses in a convergent context. Journal of Metamorphic Geology 19, 717-737. https://doi.org/10.1046/j.0263-4929.2001.00342.x

Rutte, D., Ratschbacher, L., Khan, J., Stübner, K., Hacker, B.R., Stearns, M.A., Enkelmann, E., Jonckheere, R., Pfänder, J.A., Sperner, B., Tichomirowa, M., 2017. Building the PamirTibet Plateau - Crustal stacking, Extensional Collapse, and Lateral Extrusion in the Central Pamir: 2. Timing and Rates. Tectonics 2016TC004294.

1210 de Saint Blanquat, M., Lardeaux, J.M., Brunel, M., 1990. Petrological arguments for hightemperature extensional deformation in the Pyrenean Variscan crust (Saint Barthélémy Massif, Ariège, France). Tectonophysics 233 177, 245-262. https://doi.org/10.1016/00401951(90)90284-F

de Saint Blanquat, M. de, 1993. The ductile normal fault of the Saint Barthélémy Massif Variscan 1215 evolution of the north-pyrenean catazonal massifs considered from the viewpoint of their 
thermal history. Geodinamica Acta 6, 59-77. https://doi.org/10.1080/09853111.1993.11105239

de Sitter, L.U., Zwart, H.J., 1960. Tectonic development in supra and infra-structures of a mountain chain. Proceedings of the 21st International Geological Congress of Cophenhagen 18, 248-256.

Saspiturry, N., Cochelin, B., Razin, P., Leleu, S., Lemirre, B., Bouscary, C., Issautier, B., Serrano, O., Lasseur, E., Baudin, T., Allanic, C., 2019. Tectono-sedimentary evolution of a rift system controlled by Permian post-orogenic extension and metamorphic core

1226 Schnapperelle, S., Mezger, J.E., Stipp, M., Hofmann, M., Gärtner, A., Linnemann, U., 2020. geochronology from gneiss domes of the Pyrenees. Gondwana Research 81, 291-311. https://doi.org/10.1016/j.gr.2019.11.013

Siron, G., Goncalves, P., Marquer, D., Pierre, T., Paquette, J.-L., Vanardois, J., 2020. Contribution of magmatism, partial melting buffering and localized crustal thinning on the late Variscan thermal structure of the Agly massif (French Pyrenees). Journal of Metamorphic Geology 38, 799-829. https://doi.org/10.1111/jmg.12549

Stampfli, G.M., Hochard, C., Vérard, C., Wilhem, C., vonRaumer, J., 2013. The formation of Pangea. Tectonophysics 593, 1-19. https://doi.org/10.1016/j.tecto.2013.02.037

Stephenson, B.J., Searle, M.P., Waters, D.J., Rex, D.C., 2001. Structure of the Main Central Thrust zone and extrusion of the High Himalayan deep crustal wedge, Kishtwar-Zanskar Himalaya. Journal of the Geological Society 158, 637-652. https://doi.org/10.1144/jgs.158.4.637

Stipp, M., Stünitz, H., Heilbronner, R. \& Schmid, S.M. 2002. The eastern Tonale fault zone: a 'natural laboratory' for crystal plastic deformation of quartz over a temperature range from 250 to $700^{\circ} \mathrm{C}$. Journal of Structural Geology 24, 1861-1884, https://doi.org/10.1016/S0191-8141(02)00035-4

Tapponnier, P., Peltzer, G., Dain, A.Y.L., Armijo, R., Cobbold, P., 1982. Propagating extrusion tectonics in Asia: New insights from simple experiments with plasticine. Geology 10, 611-616. https://doi.org/10.1130/0091-7613(1982)10<611:PETIAN>2.0.CO;2 
1247

1248

1249

1250

1251

1252

1253

1254

1255

1256

1257

1258

1259

1260

1261

1262

1263

1264

1265

1266

1267

1268

1269

1270

1271

1272

1273

1274

1275

1276

1277
Taylor, M., Yin, A., 2009. Active structures of the Himalayan-Tibetan orogen and their relationships to earthquake distribution, contemporary strain field, and Cenozoic volcanism Active structures on the Tibetan plateau and surrounding regions. Geosphere 5, 199-214. https://doi.org/10.1130/GES00217.1

Ternet, Y., Barrère, P., Canérot, J., Majeste-Menjoulas, C., 2004. Carte géol. France (1/50 000), feuille Laruns-Somport (1069), BRGM, Orléans.

Ternet, Y., Barrère, P., Dallas, S., Debon, F., Debroas, E.J., François, J.-M., Pouget, P., 1996. Carte géol. France (1/50 000), feuille Campan (1071), BRGM, Orléans.

Teyssier, C., Whitney, D.L., 2002. Gneiss domes and orogeny. Geology 30, 1139-1142. https://doi.org/10.1130/0091-7613(2002)030<1139:GDAO>2.0.CO;2

Tikoff, B., Russo, R., Teyssier, C., Tommasi, A., 2004. Mantle-driven deformation of orogenic zones and clutch tectonics. Geological Society, Special Publications 227, 41-64.

Torvela, T., Kurhila, M., 2020. How does orogenic crust deform? Evidence of crustal-scale competent behaviour within the partially molten middle crust during orogenic compression. Precambrian Research 342, 105670. https://doi.org/10.1016/j.precamres.2020.105670

Tournaire Guille, B., 2017. Relation entre magmatisme et métamorphisme Haute-Température Basse-Pression. Réexamen du massif de l’Agly (Pyrénées Orientales). PhD theis, Univ. Paris 6, Paris, France.

Tournaire Guille, B., Olivier, Ph., Paquette, J.-L., Bosse, V., Guillaume, D., 2019. Evolution of the middle crust of the Pyrenees during the Paleozoic: new data on the plutonic rocks from the North Pyrenean Agly Massif. International Journal of Earth Sciences 108, 245265. https://doi.org/10.1007/s00531-018-1652-4

Triboulet, C., Guitard, G., Katona, I., Navidad, M., 2005. Évolution pression-température des amphibolites de la zone axiale au cours du métamorphisme hercynien des Pyrénées orientales. Comptes Rendus Geoscience 337, 1244-1249. https://doi.org/10.1016/j.crte.2005.06.011

Tugend, J., Manatschal, G., Kusznir, N.J., Masini, E., Mohn, G., Thinon, I., 2014. Formation and deformation of hyperextended rift systems: Insights from rift domain mapping in the Bay of Biscay-Pyrenees. Tectonics 33, 2014 TC003529.

https://doi.org/10.1002/2014TC003529

This article is protected by copyright. All rights reserved. 
1278 Vacherat, A., Mouthereau, F., Pik, R., Huyghe, D., Paquette, J.-L., Christophoul, F., Loget, N., 1279 Tibari, B., 2017. Rift-to-collision sediment routing in the Pyrenees: a synthesis from 1280 sedimentological, geochronological and kinematic constraints. Earth Science Reviews 172, 43-74. http://dx.doi.org/10.1016/j.earscirev.2017.07.004

1282 Van den Eeckhout, B., Zwart, H.J., 1988. Hercynian crustal-scale extensional shear zone in the 1283 Pyrenees. Geology 16, 135-138. https://doi.org/10.1130/00917613(1988)016<0135:HCSESZ>2.3.CO;2

1285 Vanardois, J., Trap, P., Goncalves, P., Marquer, D., Gremmel, J., Siron, G., Baudin, T., 2020. Kinematics, deformation partitioning and late Variscan magmatism in the Agly massif, Eastern Pyrenees, France. Bulletin de la Société géologique de France 191. https://doi.org/10.1051/bsgf/2020009

Vanderhaeghe, O., Oscar, L., Gardien, V., Moyen, J.-F., Gébelin, A., Chelle-Michou, C., construction, growth and collapse of the Variscan orogenic belt: 1 the geologic record of the French Massif Central. Bulletin de la Société géologique de France 191,

1294 Vanderhaeghe, O., Teyssier, C., 2001. Partial melting and flow of orogens. Tectonophysics 342, 451-472. https://doi.org/10.1016/S0040-1951(01)00175-5

1296 Van Lichtervelde, M., Grand'Homme, A., Saint-Blanquat, M. de, Olivier, P., Gerdes, A.,

1297 Paquette, J.-L., Melgarejo, J.C., Druguet, E., Alfonso, P., 2017. U-Pb geochronology on 1298 zircon and columbite-group minerals of the Cap de Creus pegmatites, NE Spain.

1299 Mineralogy and Petrology 111, 1-21. https://doi.org/10.1007/s00710-016-0455-1

1300 Vielzeuf, D., 1984. Relations de phases dans le faciès granulite et implications géodynamiques:

$1301 \quad$ l'exemple des granulites des Pyrénées. PhD thesis, Univ. Clermont Ferrand, France.

1302 Vilà, M., Pin, C., Liesa, M., Enrique, P., 2007. LP-HT metamorphism in a late orogenic 1303 transpressional setting, Albera Massif, NE Iberia: implications for the geodynamic evolution of the Variscan Pyrenees. Journal of Metamorphic Geology 25, 321-347. https://doi.org/10.1111/j.1525-1314.2007.00698.x

1306 von Raumer, J.F., Bussy, F., Schaltegger, U., Schulz, B., Stampfli, G.M., 2013. Pre-Mesozoic Alpine basements-Their place in the European Paleozoic framework. GSA Bulletin 125, 1308 89-108. https://doi.org/10.1130/B30654.1 
Weil, A., Gutiérrez-alonso, G., Conan, J., 2010. New time constraints on lithospheric-scale oroclinal bending of the Ibero-Armorican Arc: a palaeomagnetic study of earliest Permian rocks from Iberia. Journal of the Geological Society 167, 127-143. https://doi.org/10.1144/0016-76492009-002

Weil, A.B., 2006. Kinematics of orocline tightening in the core of an arc: Paleomagnetic analysis of the Ponga Unit, Cantabrian Arc, northern Spain. Tectonics 25. https://doi.org/10.1029/2005TC001861

Weil, A.B., Gutiérrez-Alonso, G., Johnston, S.T., Pastor-Galán, D., 2013. Kinematic constraints on buckling a lithospheric-scale orocline along the northern margin of Gondwana: A geologic synthesis. Tectonophysics 582, 25-49. https://doi.org/10.1016/j.tecto.2012.10.006

White, A.P., Hodges, K.V., Martin, M.W., Andresen, A., 2002. Geologic constraints on middlecrustal behavior during broadly synorogenic extension in the central East Greenland Caledonides. International Journal of Earth Sciences 91, 187-208. https://doi.org/10.1007/s005310100227

Whitney, D.L., Teyssier, C., Vanderhaeghe, O., 2004. Gneiss domes and crustal flow. Geological Society of America Special Papers 380, 15-33. https://doi.org/10.1130/0-8137-2380-9.15

Worthington, J.R., Ratschbacher, L., Stübner, K., Khan, J., Malz, N., Schneider, S., Kapp, P., Chapman, J.B., Goddard, A.S., Brooks, H.L., Lamadrid, H.M., Steele-MacInnis, M., Rutte, D., Jonckheere, R., Pfänder, J., Hacker, B.R., Oimahmadov, I., Gadoev, M., 2020. The Alichur Dome, South Pamir, Western India-Asia Collisional Zone: Detailing the Neogene Shakhdara-Alichur Syn-collisional Gneiss-Dome Complex and Connection to Lithospheric Processes. Tectonics 39, e2019TC005735. https://doi.org/10.1029/2019TC005735

Yin, A., 2004. Gneiss domes and gneiss dome systems. Geological Society of America Special Papers 380, 1-14.

Zhang, Z., Sun, J., 2020. Cenozoic tectonic rotations in different parts of the NE Pamir: implications for the evolution of the arcuate orogen. International Journal of Earth Sciences 109, 1921-1939. https://doi.org/10.1007/s00531-020-01880-2

Zwart, H.J., 1979. The geology of the Central Pyrenees. Leidse Geol. Mededelingen 50, 1-74.

This article is protected by copyright. All rights reserved. 


\section{Figure captions:}

1342 Figure 1: Structural sketch of the Variscan belt at late Carboniferous times. Source maps from 1343 geodynamic reconstitution are from Franke (2014) for the northern realm of the Variscan belt and 1344 Stampfli et al., (2013) for the southern realm (Alleghanian belt, Alpine Mediterranean domain, 1345 and Paleotethys) with modifications for Corsica, Sardinia, and Maures-Tanneron relative 1346 positions by considering recent paleomagnetic syntheses by Edel et al., (2014, 2018). Directions 1347 of stretching are represented only for the 310-290 Ma period, and were synthesized from (1) 1348 Michard et al., (2010); (2) review from Martínez Catalán et al., (2014); (3) Cochelin et al., 1349 (2017); (4) Corsini and Rolland, (2009); (5) Carosi and Palmeri, (2002); (6) Casini et al., 2012; 1350 (7) Choulet et al., (2012); (8) Ledru et al., (2001); (9) Echtler and Malavieille (1990); (10) Faure 1351 et al., (1990); (11) Faure et al., (2009); (12) Genna et al., (1998); Rolin and Colchen (2001); (13) 1352 Review from Gapais et al., (2015); (14) Saspiturry et al., (2019); (15) Carreras and Debat (1996); 1353 (16) de Saint Blanquat (1993); (17) Díez Fernández et al., (2012); (18) Escuder Viruete et al., 1354 (1998); (19) Hernández Enrile (1991). Abbreviations: CZ Cantabrian Zone, CIZ: Central Iberian 1355 Zone, FMC: French Massif Central, AM: Armorican Massif, BM: Bohemian Massif, MN:

1356 Montagne Noire; MT: Maures-Tanneron; CS: Corsica-Sardinia. In the Pyrenees, only the 1357 direction of stretching associated with thrusting is shown.

1358 Figure 2: a) Geological map of the Variscan domains of the Pyrenees, modified from Cochelin et 1359 al., (2017); (b) Available U-Pb ages for metamorphic rocks and granitoids; (c) P-T diagram 1360 showing the P-T paths from the gneiss domes of the Axial Zone, estimations of peak 1361 metamorphism and the range of pressure for emplacement of upper crustal plutons. Aston: 1362 Mezger and Régnier, (2016); Canigou: de Hoÿme de Marien et al., (2019); Bossost: Mezger et 
1363 al., (2004); Roc de France: Aguilar et al., (2015); Albères: Vilà et al., (2007). Range of pressure 1364 for pluton emplacement after Autran et al., (1970); Debon et al., (1996); Evans et al., (1998);

1365 Poitrenaud, (2018); Synthetic P-T diagrams representing estimations of the metamorphic peak in 1366 the Axial Zone (d) and the North Pyrenean Massifs (e). Estimates are from Pouget (1989) ; Ayora 1367 et al., (1993); Guitard et al., (1996); Vilà et al., (2007); Mezger and Régnier, (2016) ; Mezger et 1368 al., (2004); Triboulet et al., (2005); Lemirre et al., (2019) in the Axial Zone and from Andrieux, 1369 (1982); Vielzeuf, (1984); Mendia and Gil Ibarguchi, (1991); de Saint Blanquat et al., (1990);

1370 Giró and Alías López, (2007); Tournaire Guille, (2017) ; Siron et al., (2020) for the North 1371 Pyrenean Massifs.

1372 Figure 3: Structural map of the Variscan domains from the Pyrenees, modified from Cochelin et 1373 al., (2017).

1374 Figure 4: a) Simplified geological map of the studied area, modified from Pouget (1984) and 1375 Ternet et al., (1996) with the integration of new field surveys. Cross-sections presented in Figure 13766 are localized. A detailed high-resolution geological map is reported in Supporting Information; 1377 b) Structural map of the studied area. Foliation trajectories are inferred from Pouget (1984), 1378 Ternet et al., (1996), and our measurements; A.R.: Aigue-Rouye sub-dome.

1379 Figure 5: Stereogram of poles to foliation or schistosity (i.e., Si and Ss) in the lower, transitional 1380 and upper domains (lower hemisphere; contours=1\%). The associated lineations Li or Ls and 1381 kinematics are also reported.

1382 Figure 6: Transverse and longitudinal cross-sections across the Chiroulet and Lesponne gneiss 1383 domes.

This article is protected by copyright. All rights reserved. 
1384 Figure 7: Photographs of gneiss, micaschists, and marbles from the Chiroulet and Lesponne 1385 gneiss domes. a) Meter scale sill of porphyritic leucogranite from the Lesponne dome showing a 1386 magmatic foliation Si; b) Well-defined shallowly dipping magmatic foliation Si in diorite from 1387 the Lesponne dome; c) Mineral lineation (Li) defined by the alignment of biotite, sillimanite, and 1388 feldspars within diatexites from the Chiroulet dome. d) Mineral-stretching lineation within 1389 amphibolite boudins in migmatites from the Chiroulet dome; e) Domino-like boudinage in calc1390 silicate gneiss at the top of the migmatites from the Chiroulet dome; f) Interference pattern 1391 showing passive reorientation of Li stretching lineation in the hinge of late folds, called Fs 1392 (location: Pic du Midi); g) Typical crenulation of the Si foliation by Ss cleavage in the flank of 1393 regional folds (location: Pic du Midi); h) stretching striae-lineation Ls associated with Ss foliation 1394 within Devonian marbles.

1395 Figure 8: Field photographs of the transitional domain in the southern flank of the Chiroulet 1396 dome: a) Panorama of the southern transition between the lower and the transitional domains of 1397 the Chiroulet dome, located at the top of migmatites. The difference of deformation patterns is 1398 well illustrated, with a poorly disturbed shallowly dipping foliation (Si) in migmatites or Silurian 1399 paragneisses and the same fabric in Devonian series that is intensively folded and sheared by 1400 reverse shear zones; b) Style of deformation within Lower Devonian marbles and 1401 marble/sandstone alternations (location: north-western side of the Lac Bleu), with zooms c) and 1402 d) on folded boudins in these layers; e) sub-vertical mylonitic foliation within marble layers and 1403 asymmetrical boudinage showing south side up kinematics.

1404 Figure 9: Field photographs from the marbles and schists of the upper domain. a) \& a') High1405 strain fabric in Lower Devonian marbles showing non-coaxial "top to the north" shearing at all 1406 scale (location: Lac Bleu, see also Fig. 8); b) Non-coaxial "top to the north" shearing within low- 
1407 grade middle Devonian schists in the southern flank of the Lesponne dome; c) Low-grade shear 1408 band affecting the diatexites from the Chiroulet dome. Steep C' shears show dextral kinematics;

1409 d) \& d') Post-Variscan reverse faulting showing reactivation of earlier metamorphic fabric (e.g.

1410 Si foliation) and affecting a Permian andesitic dyke (location: north of the Tourmalet pass).

1411 Figure 10: Microphotographs from the various rock types of the Chiroulet and Lesponne area.

1412 The cross-section (a) (i.e., cross-section 2 in Figure 6) represents their localization at various

1413 structural levels. b) Si foliation in paragneisses, defined by oriented feldspars, quartz, and

1414 phyllosilicates. Quartz grains show evidence of deformation bands as well as dynamic

1415 recrystallization by grain boundary migration; c) Si foliation and C/S structures in sillimanite-

1416 bearing micaschists from the lower domain. Si and C' planes are defined by the alignment of

1417 biotite, sillimanite, and quartz layers. Evidence of biotite and sillimanite pinning effect in quartz

1418 grain boundaries underline dynamic recrystallization by grain boundary migration; d) Calc-

1419 silicate gneiss at the top of the lower domain. Garnet-rich layers are boudinaged and inter-

1420 boudins are filled by quartz and calcite-epidote veins. Same sample than shown in Fig. 7e; d')

1421 Zoom on the quartz-vein, where quartz grains are recrystallized by grain boundary migration; e)

1422 Quartz-rich paragneiss with a core and mantle texture, the core corresponds to garnet and ribbon

1423 quart grains (Qtz1) and the mantle to a fine-grained matrix of dynamically recrystallizes quartz

1424 (Qtz2) and muscovite; e') Same quartz-rich paragneiss showing Si/Ss relationships. Note that

1425 prismatic sillimanites are truncated when reworked by Ss; f) Andalusite-bearing schist where Ss

1426 schistosity reworked the Si foliation. Andalusites are partially retrogressed into a fine white mica

1427 and chlorite assemblage; f') Zoom on the same rocks showing inclusions of an early fabric within

1428 andalusite porphyroclast; f' ') Zoom on the same rocks showing dynamically recrystallized quartz

1429 grains by sub-grain rotation in the matrix; g and g') Chlorite-muscovite bearing Carboniferous

This article is protected by copyright. All rights reserved. 
1430 sandstones showing a dissolution pattern. Quartz grains showing recrystallization by bulging in

1431 the matrix and undoluse extinction in porphyroclasts. The cleavage is steeply dipping to the

1432 north. Mineral abbreviations are from Kretz, (1983).

1433 Figure 11: Block-diagrams and synthetic P-T diagrams illustrating the three-stage evolution of

1434 the Chiroulet and Lesponne area. a) The initiation of the thermal anomaly in the lower crust,

1435 leading to the partial melting of the crust. It took place after an earlier stage of deformation D1

1436 that is responsible for the formation of regional NW-SE trending folds. The base of Upper

1437 Paleozoic limestones is reached by the thermal anomaly in the regional synclines, allowing

1438 significant weakening of the upper crust; b) Between 310 and $300 \mathrm{Ma}$, the mid-lower crust is

1439 partially molten and flows longitudinally under N-S shortening-dominated transpression.

1440 Migmatites are partially exhumed from ca. $4.2 \mathrm{kbar}$ to $2.9 \mathrm{kbar}$, forming gneiss domes due to

1441 gravity instabilities and strain partitioning. This is marked by the activation of a decollement

1442 level in the thick Devonian marbles. Calc-alkaline plutons intrude the upper crust at this period

1443 while smaller dioritic sheets are stocked at the rheological boundary between infrastructure and

1444 superstructure; c) The cooling of the crust during N-S convergence led to the final crystallization

1445 of magma at $290 \mathrm{Ma}$, after the emplacement of the leucogranite sheets in gneiss domes. Regional

1446 cooling induced strain localization into steep transpressional shear zones and led to amplification

1447 of the domal shapes by folding. Abbreviation: WS: Wet Solidus.

1448 Figure 12: Illustration of how strain was partitioned within the Variscan belt in map view (b) and 1449 as block-diagrams (a), (c), (d): a) Conceptual model of an opposite direction of extrusion of the

1450 crust under convergence and its relationship with local transverse extension in a few North

1451 Pyrenean Massif.; b) Localisation of the Pyrenees and the highly shortened domains within the

1452 Variscan belt at the Carboniferous-Permian boundary. The Cantabrian Zone and the Pyrenean

This article is protected by copyright. All rights reserved. 
1453 Axial Zone form a ca. $100 \mathrm{~km}$ wide and $800 \mathrm{~km}$ long continuous shortened belt. c) Conceptual 1454 model of lateral escape having taken place in the Armorican massif, after Gumiaux et al., (2004) 1455 and Gapais et al., (2015); d) Conceptual model of transverse extension in the Eastern Massif 1456 Central, after Vanderhaeghe et al., (2020). Further explanation in the text.

1457 Figure 13: Comparison of strain patterns in a context of bending orogenic belts: a) The Variscan 1458 belt during the formation of the Cantabrian orocline and late-orogenic plate reorganization, at 1459 305-295 Ma. The thermal state of the lithosphere is considered following the evidence of ductile 1460 deformations and metamorphism that took place at 305-295 Ma; b) Main tectonic features of 1461 the western edge of the Himalayan-Tibet system. The collision led to westward extrusion of the 1462 orogenic plateau during the formation of the Pamir syntax. Modified from Rolland et al., (2001); 1463 Vanderhaghe \& Teyssier (2001); Rutte et al., (2017) \& Worthington et al., (2020). Further details 1464 in the text. Abbreviations: CP: Central Pamir; SP: South Pamir, K: Karakorum; MCT: Main 1465 Central Thrust; MBT: Main Boundary Thrust; STD: South Tibetan Detachment.

This article is protected by copyright. All rights reserved. 


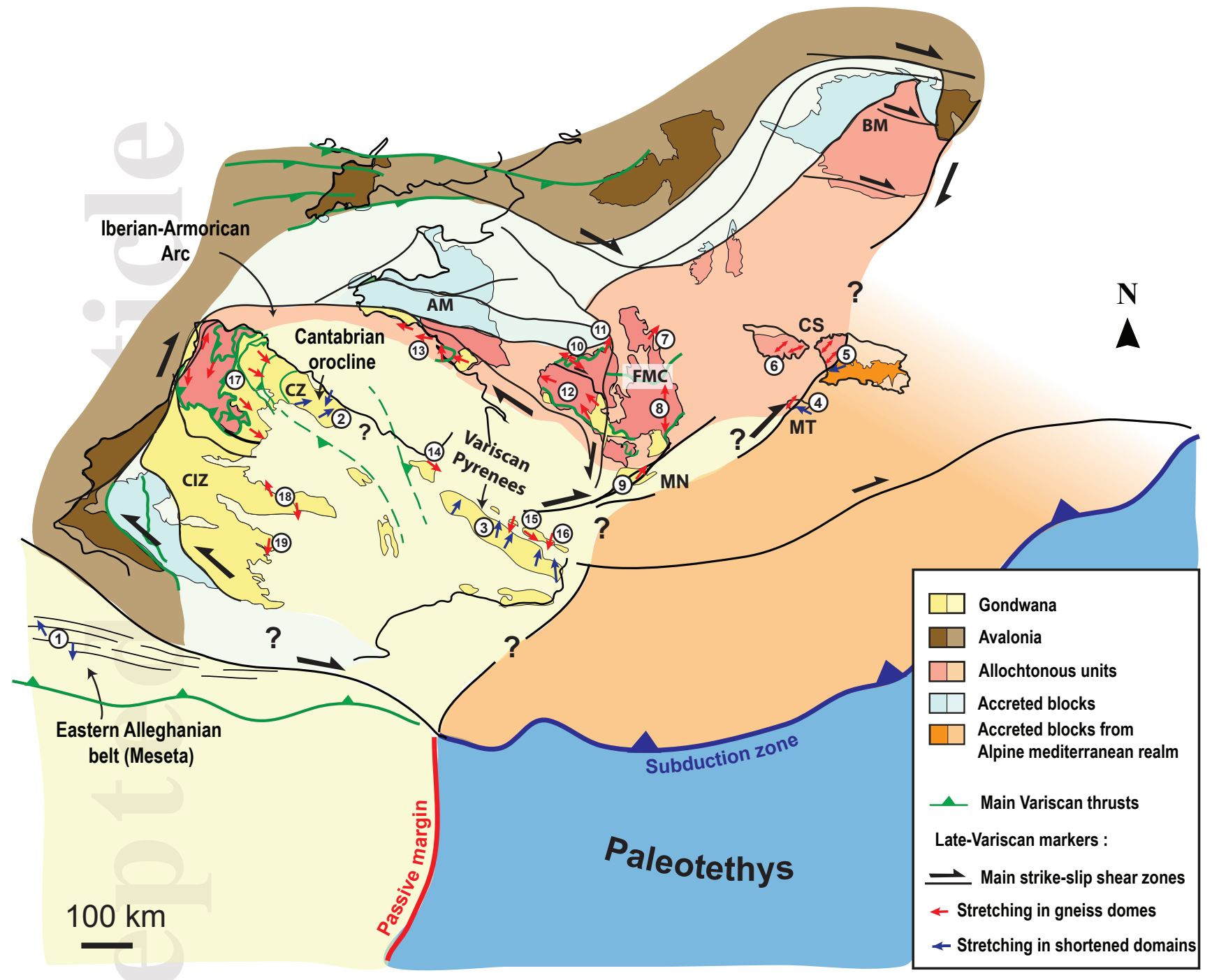

This article is protected by copyright. All rights reserved. 
(a)

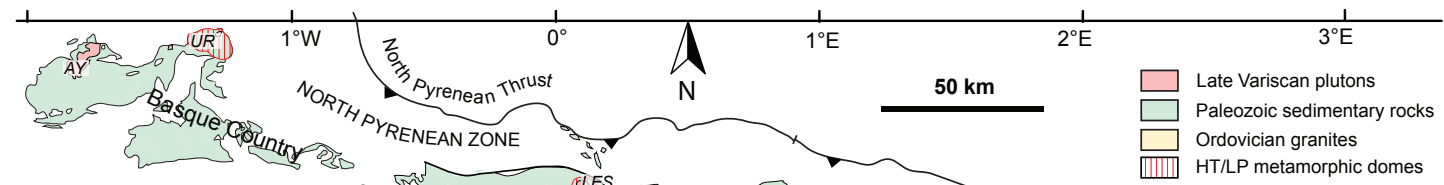

(b)

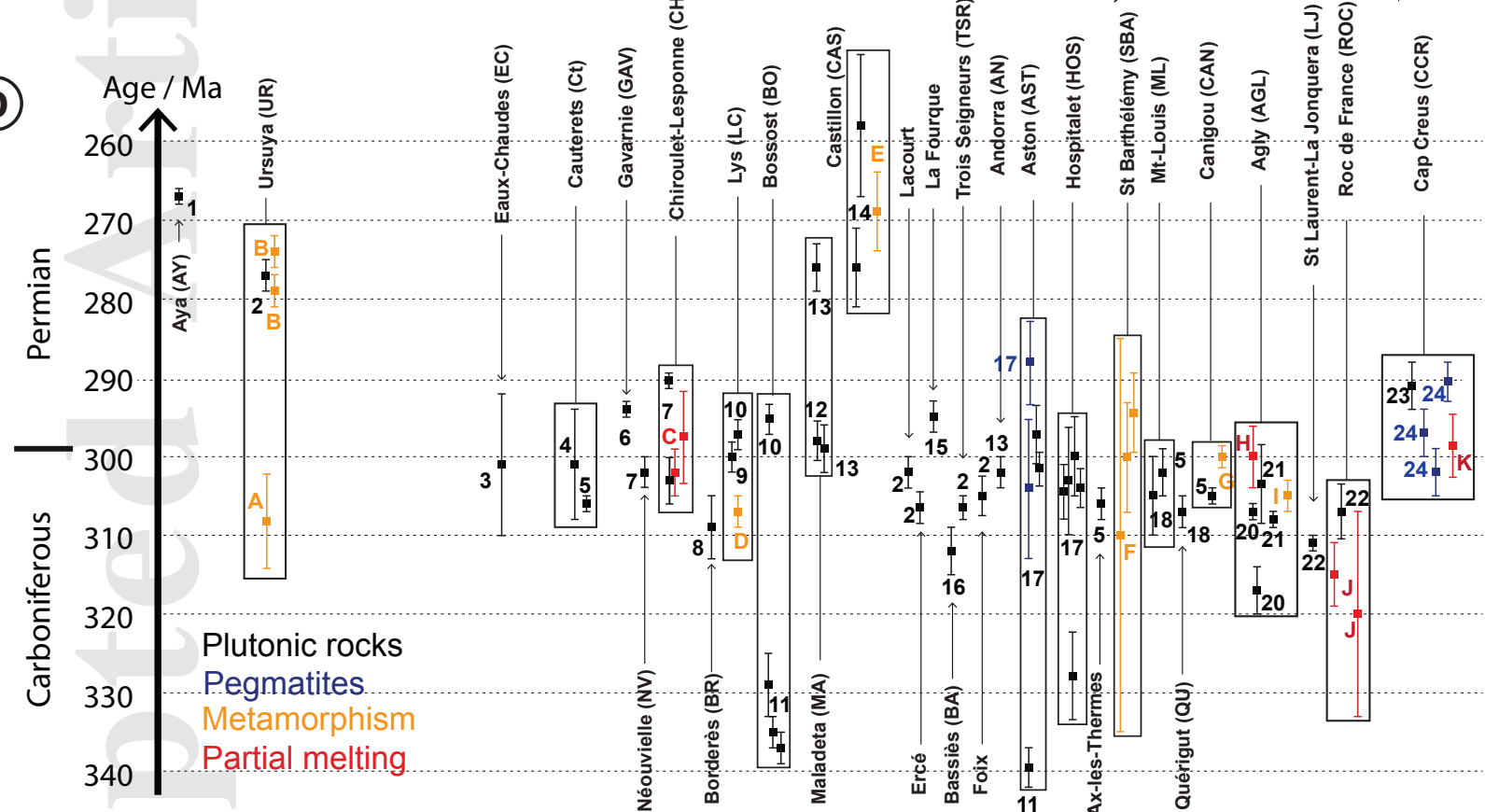

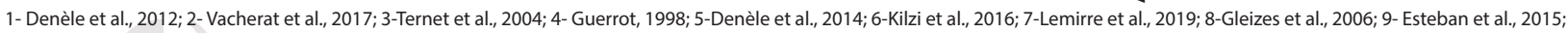

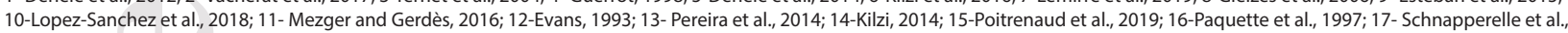
2020; 18-Maurel et al., 2004; 19-Roberts et al., 2000; 20-Olivier et al., 2004; 21-Olivier et al., 2008; 22- Aguilar et al., 2014; 23-Druguet et al., $2014 ; 24$ - Van Lichtervelde et al., 2017.

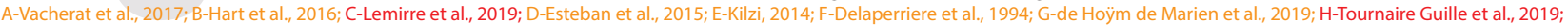
I- Siron et al., 2020; J-Aguilar et al., 2014; K- Druguet et al., 2014.
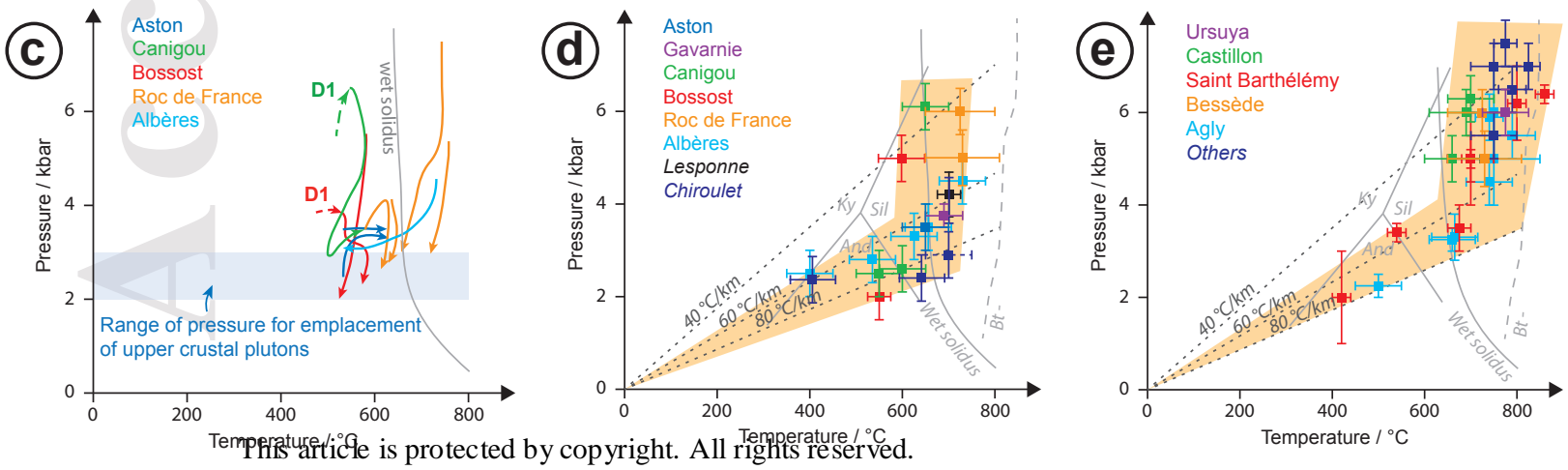


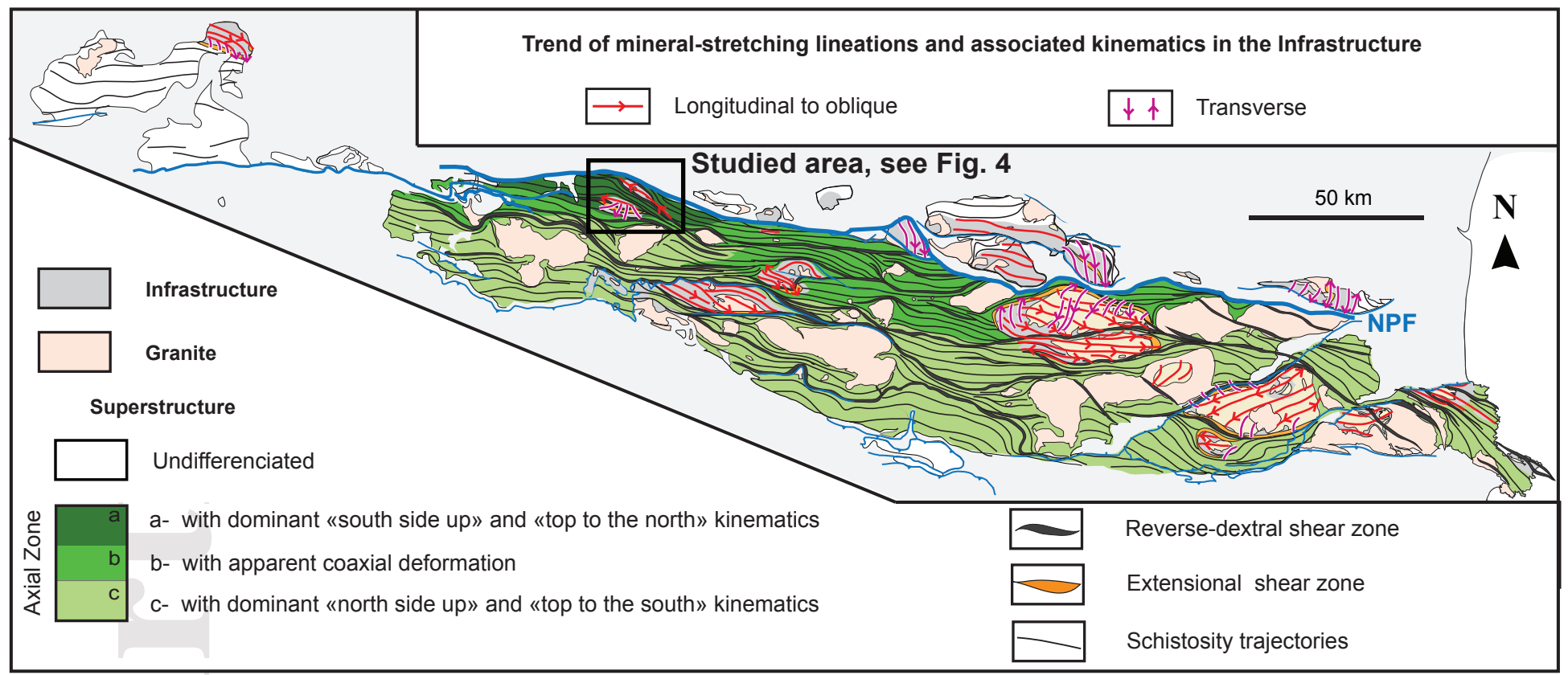

This article is protected by copyright. All rights reserved. 


\section{Meta-sedimentary rocks}

Post-Carboniferous

Carboniferous (Flysch)

Upper Devonian limestones or marbles

Middle Devonian schists

Lower Devonian schists and marbles

Silurian black shales

Cambrian to Ordovician sandstones and schists

Migmatites

\section{Magmatic rocks}

Calc-alkaline pluton

Pegmatite

Diorite (Lesponne)

Leucogranite

\section{Isograds}

$\longrightarrow$ Sillimanite isograd

- Andalusite isograd

(1) $\dashv \quad \begin{aligned} & \text { Cross-se } \\ & \text { Figure } 6\end{aligned}$ a)

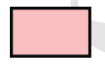

Geology

Magmatic bodies

$\square$ Sillimanite zone

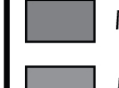

Migmatites

(b)

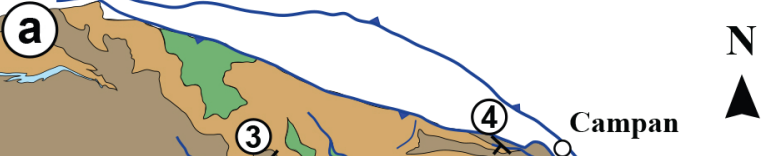

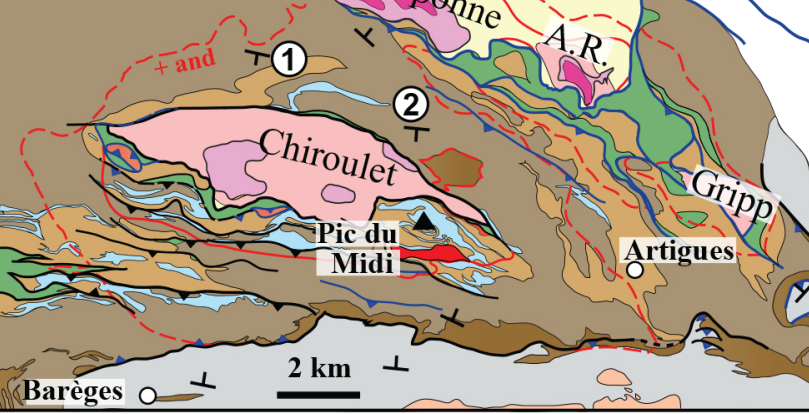

Structures

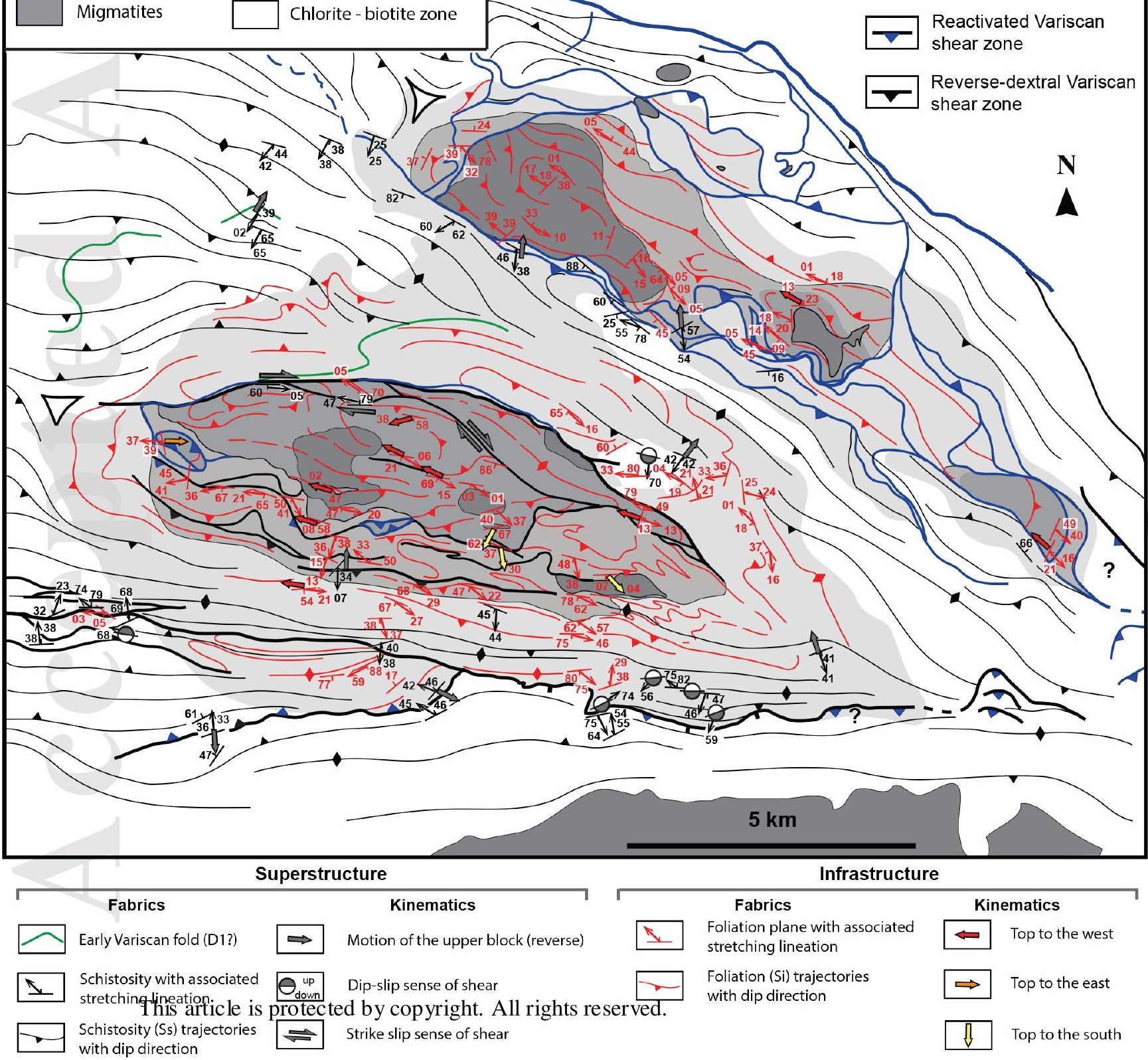




\section{Lower unit}

Transitional unit

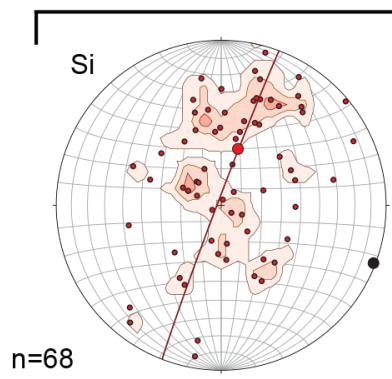

- Computed best

fold axis: $111^{\circ} / 01^{\circ}$

- Mean pole to foliation: $18 \% 62^{\circ}$

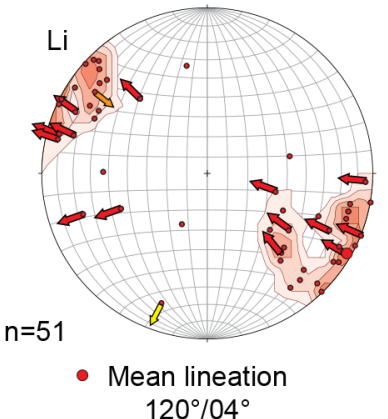

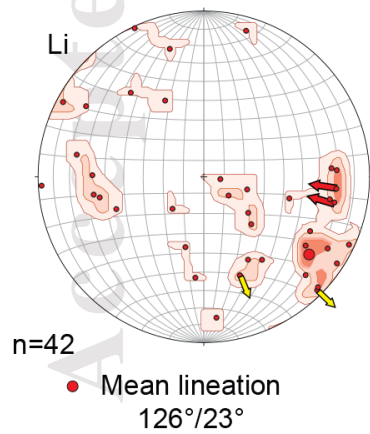

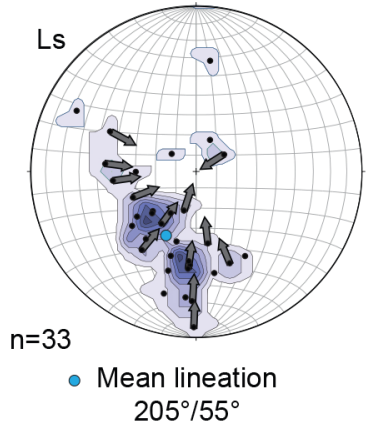

Mean foliation

N102E, 43S

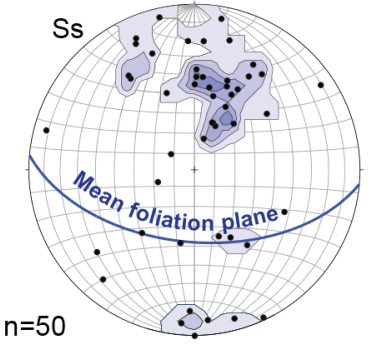

Mean foliation: N95E, 54S
Upper unit

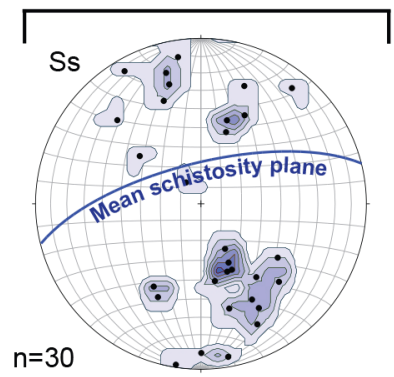

Mean schistosity: N76E, 70N

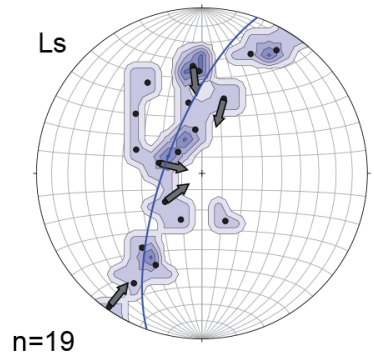

Best fit great circle N200E,72W 


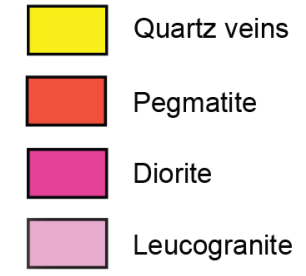




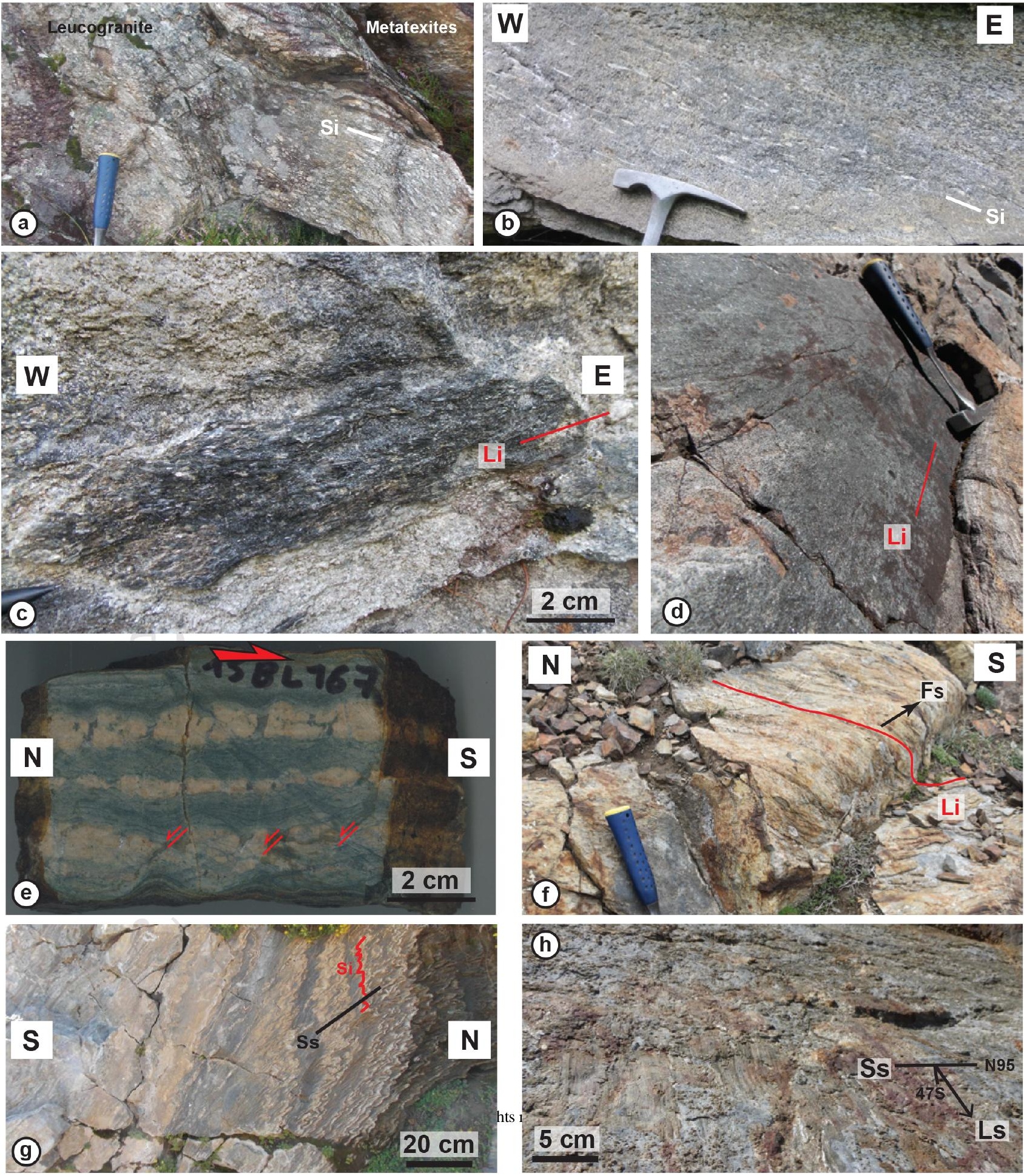




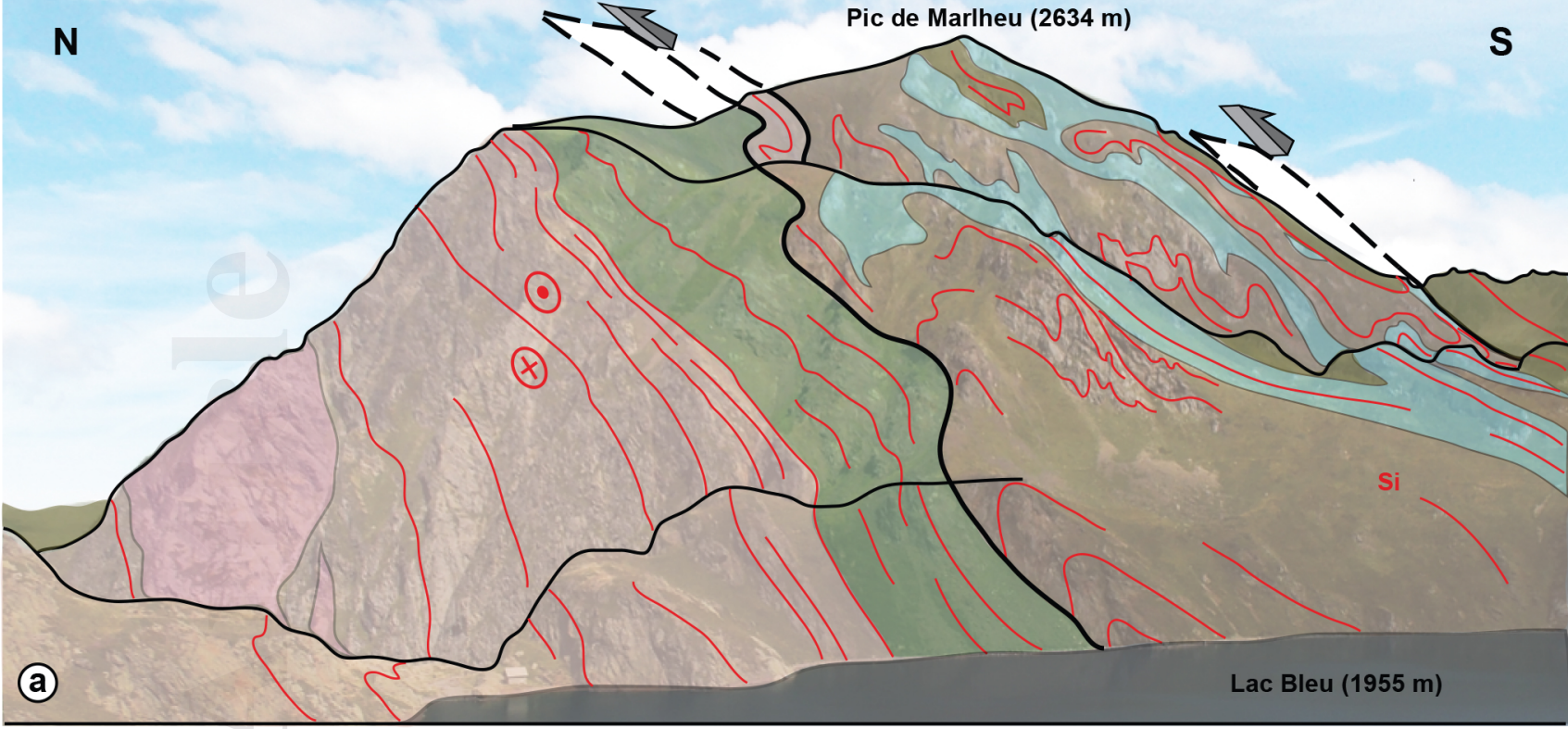

(a)

Schists (Middle Devonian)

Marble (Lower Devonian)
Marble-sandstone alternations (Lower Devonian)

Dark schists and paragneiss (Silurian)
Migmatites

Leucogranite

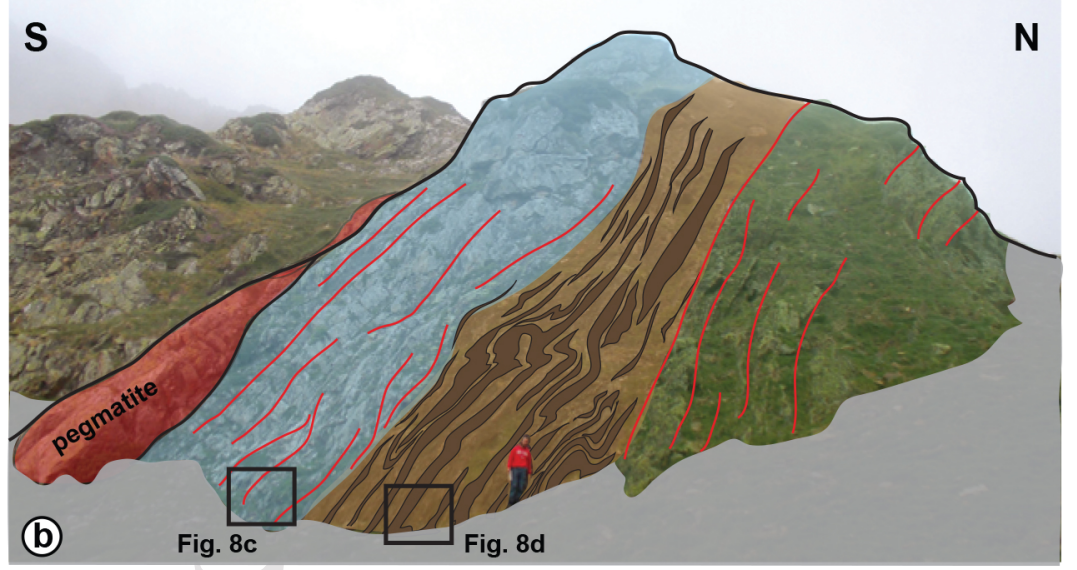

(c)

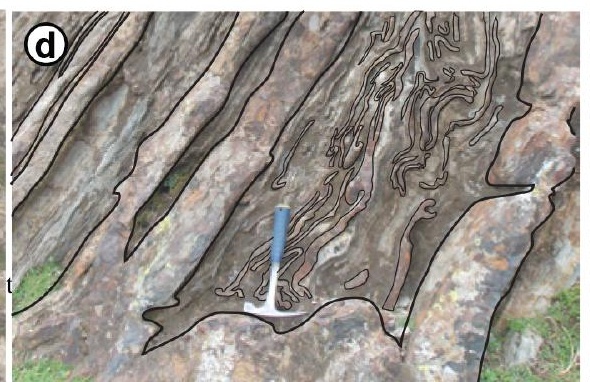

(e) 


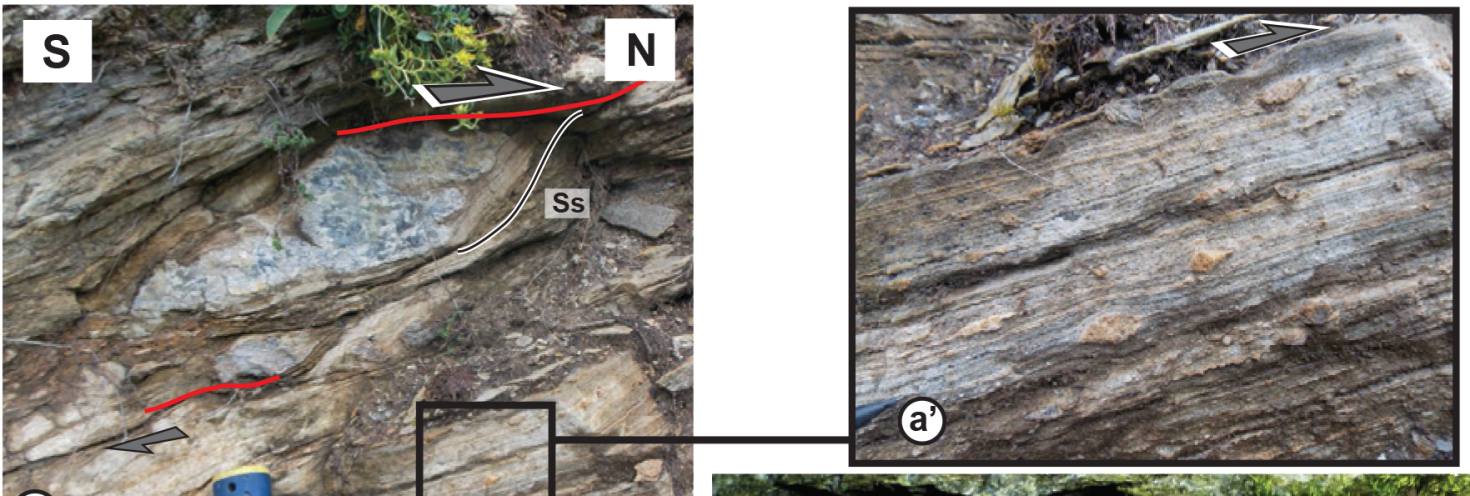

(a)
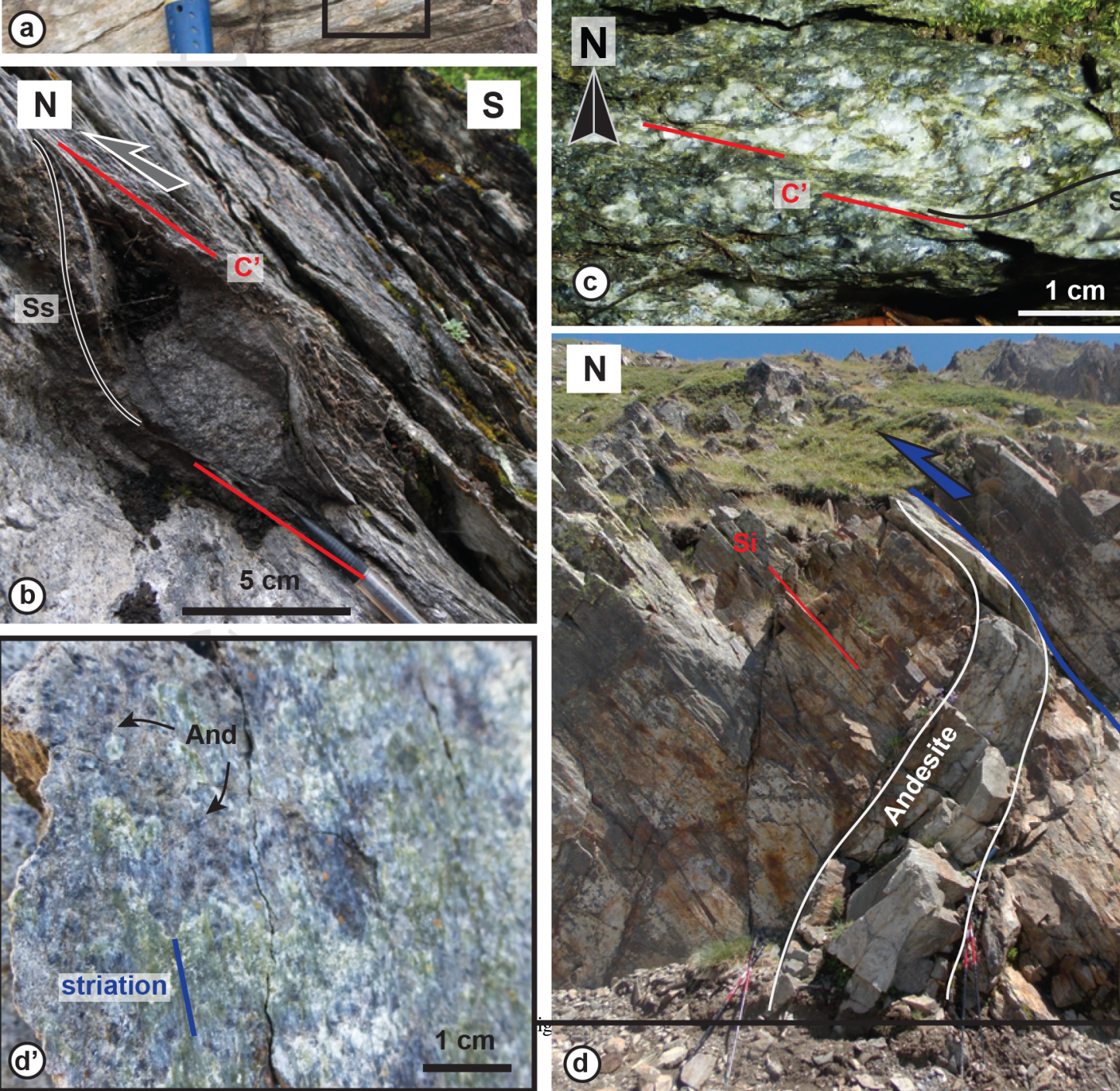

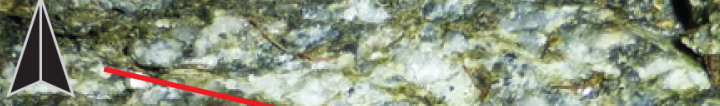

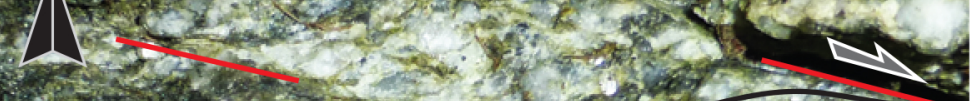

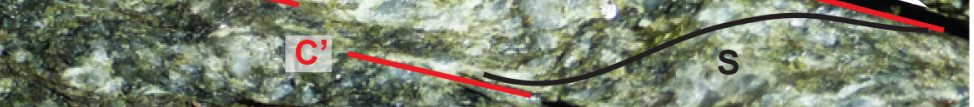

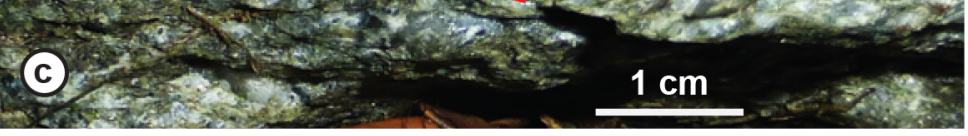

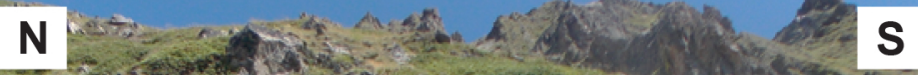

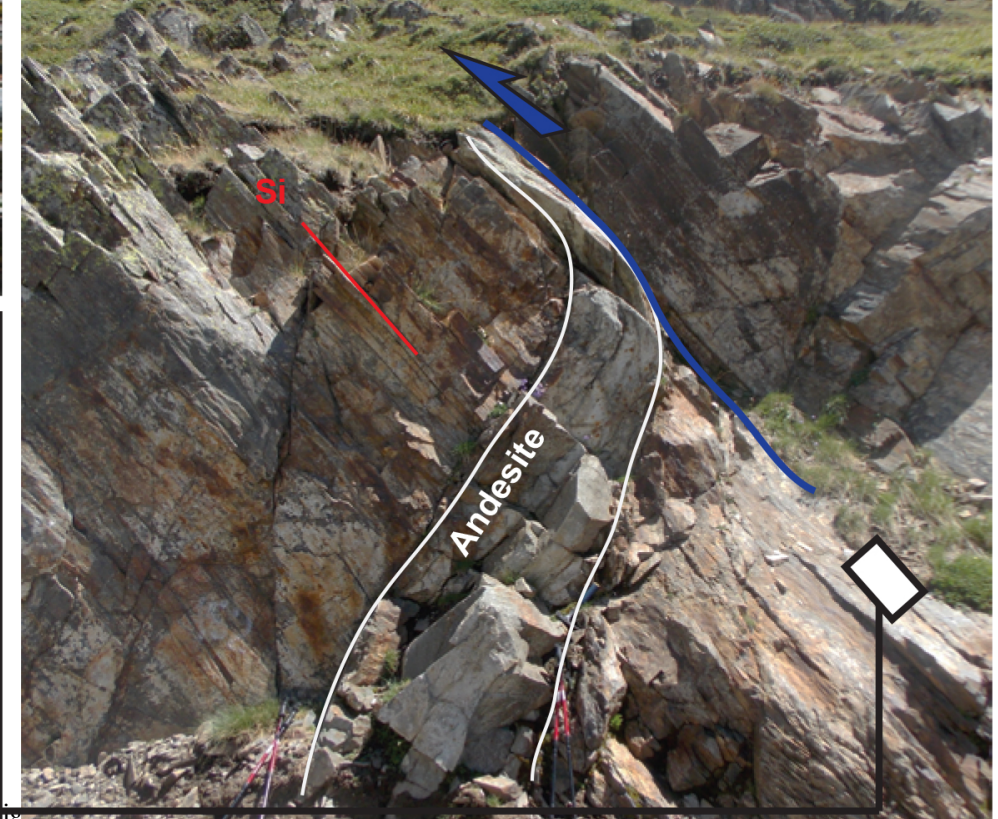

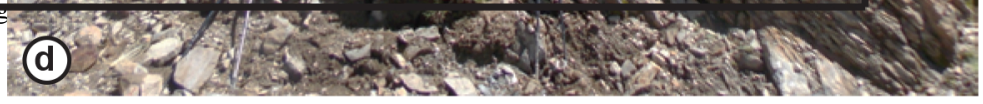




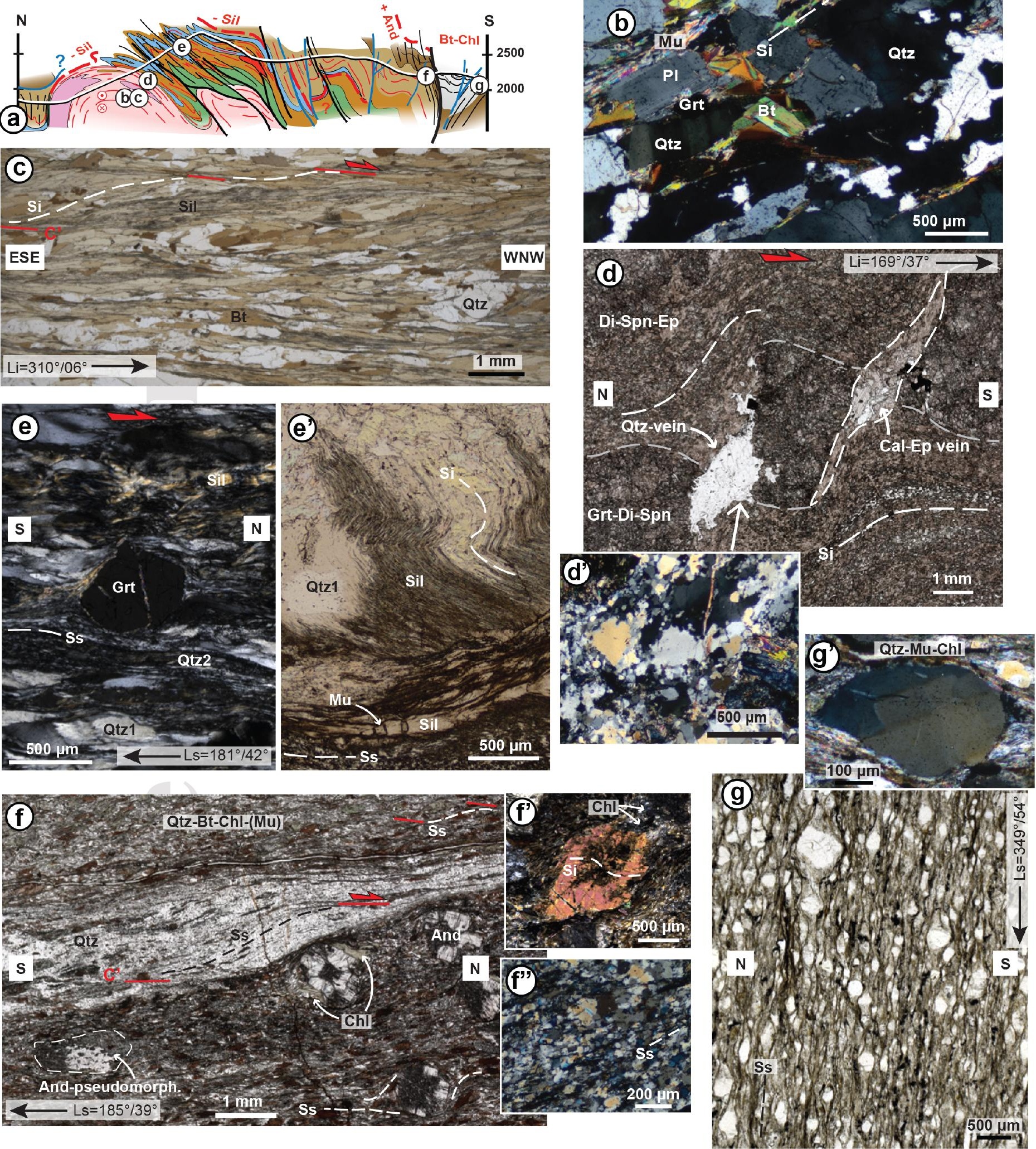




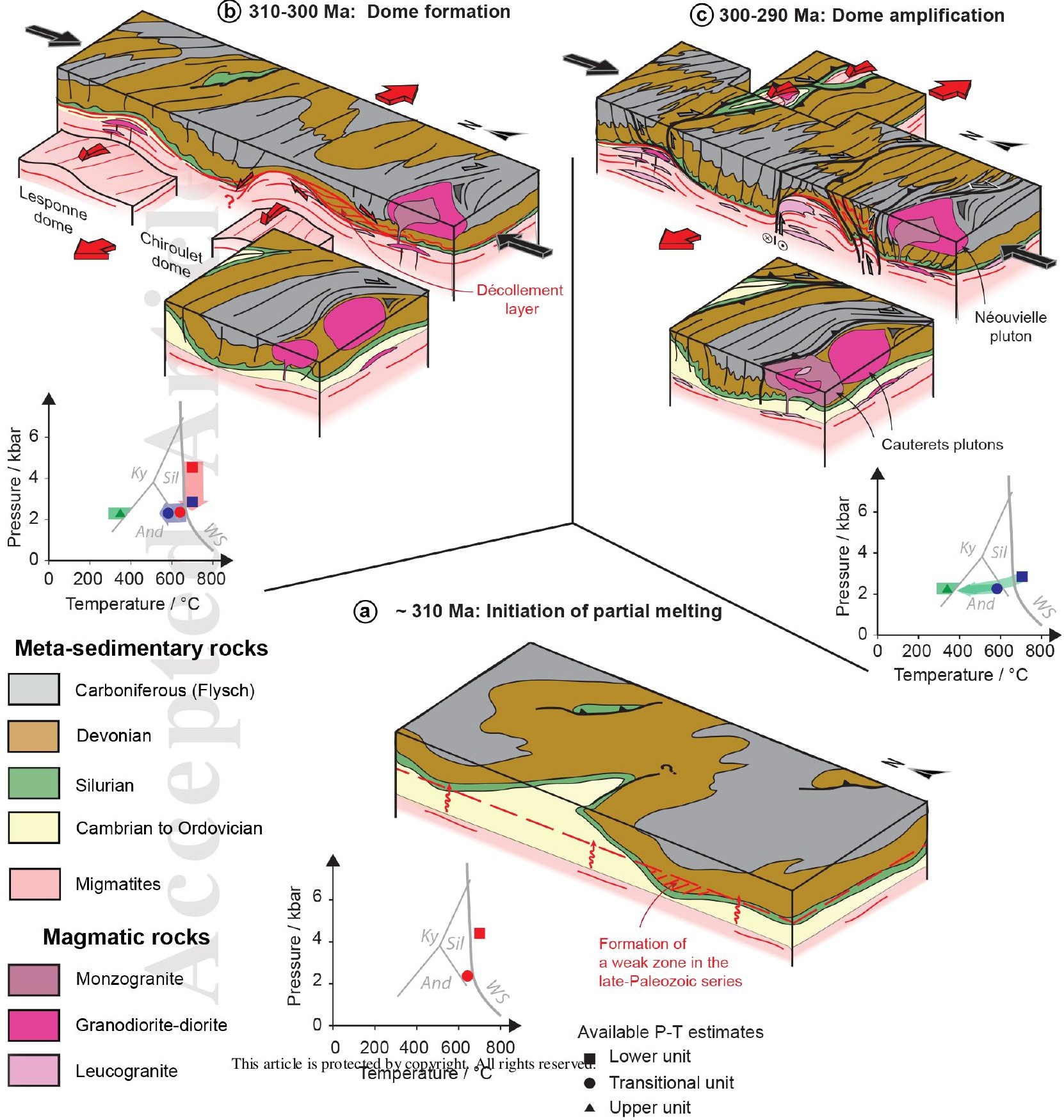


(C) Lateral escape
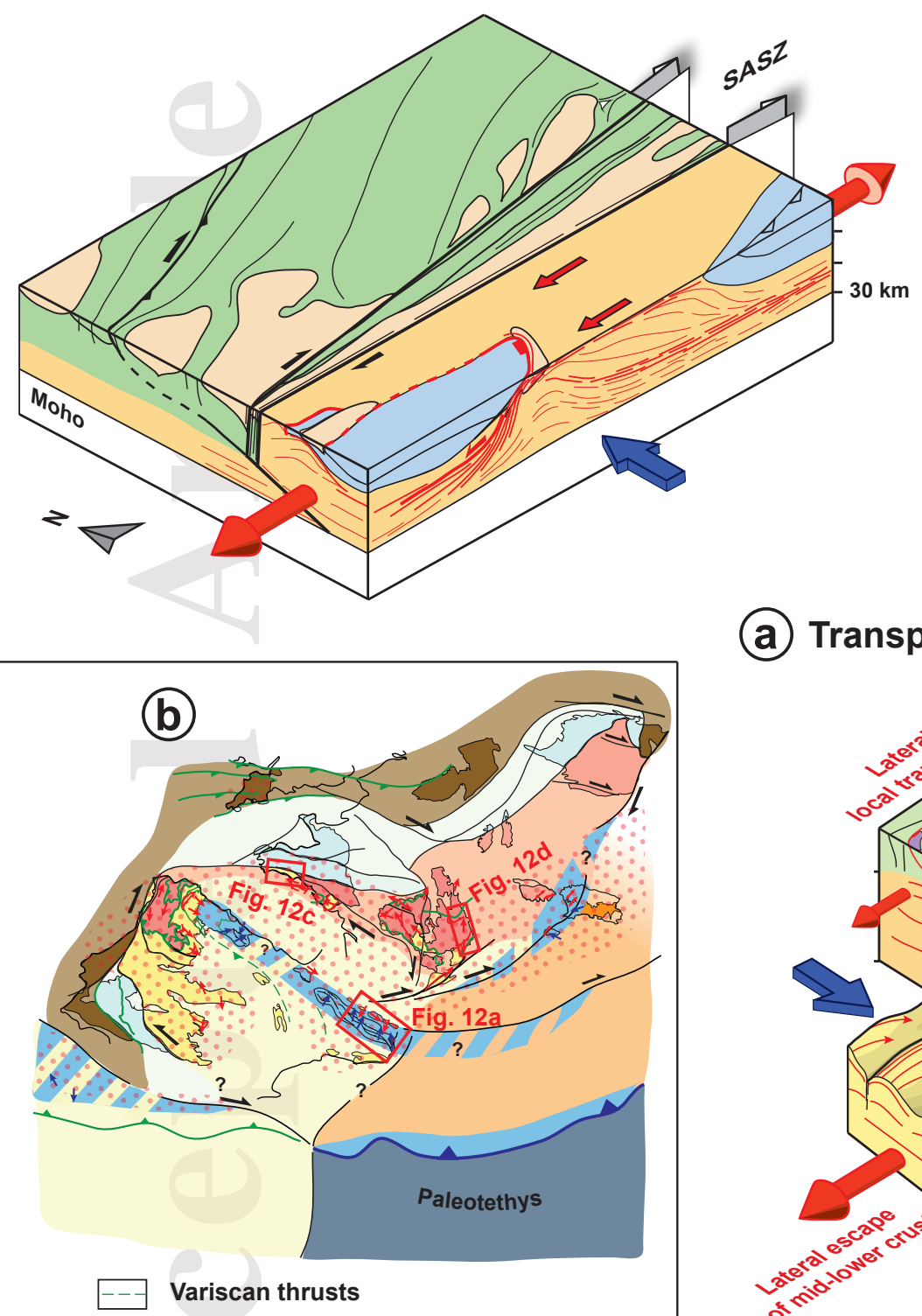

Late Variscan shear zones

(310-290 Ma)

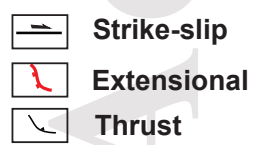

Domain subjected to

compression / transpression

$\because$ Domain affected by Late-Variscan (a) Transpression

(d) Transverse extension
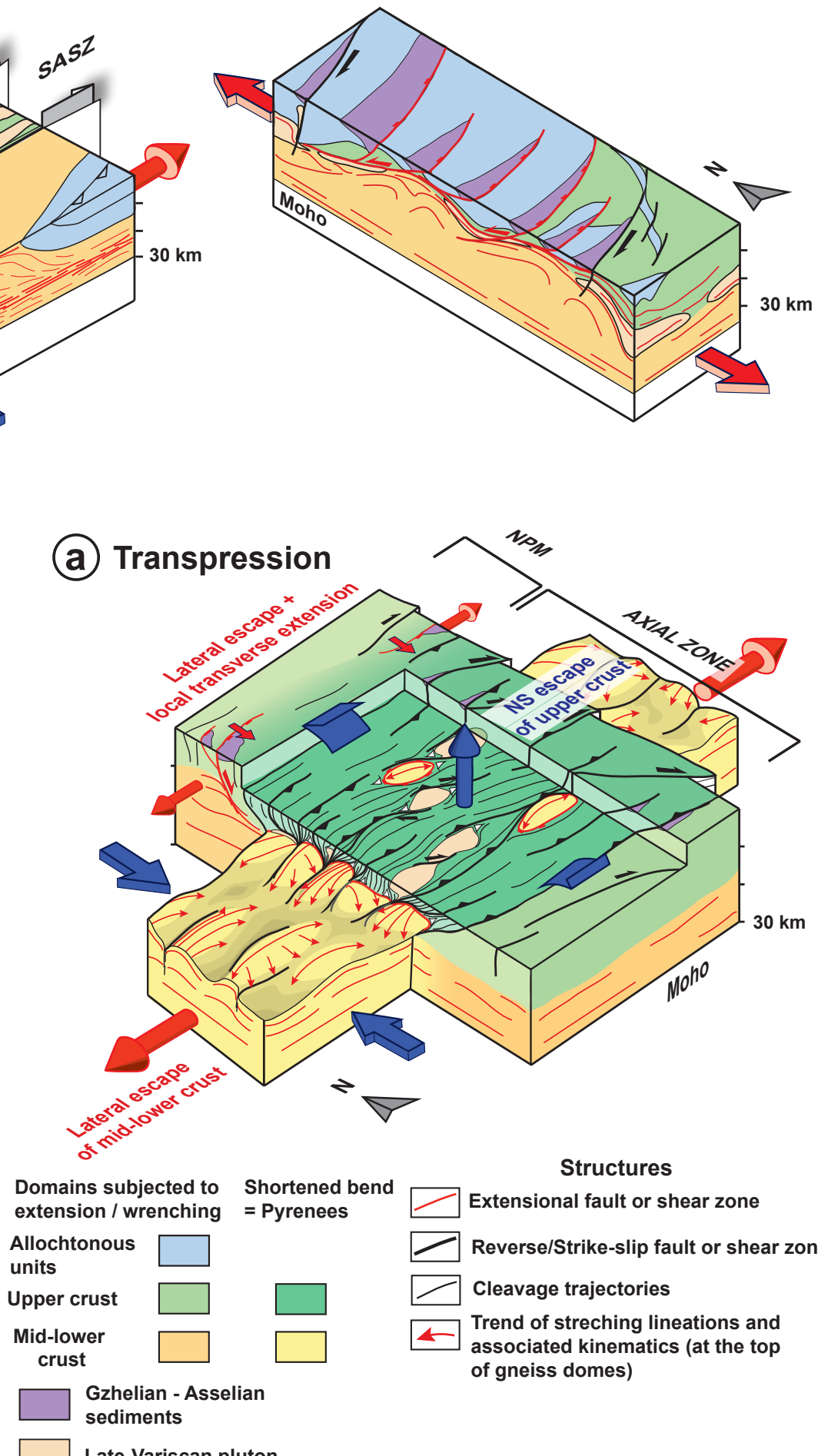

Structures

Extensional fault or shear zone

Reverse/Strike-slip fault or shear zone

Cleavage trajectories

Trend of streching lineations and associated kinematics (at the top of gneiss domes)

HT/LP metamorphism and magmatism Late-Variscan pluton This article is protected by copyright. All rights reserved. 

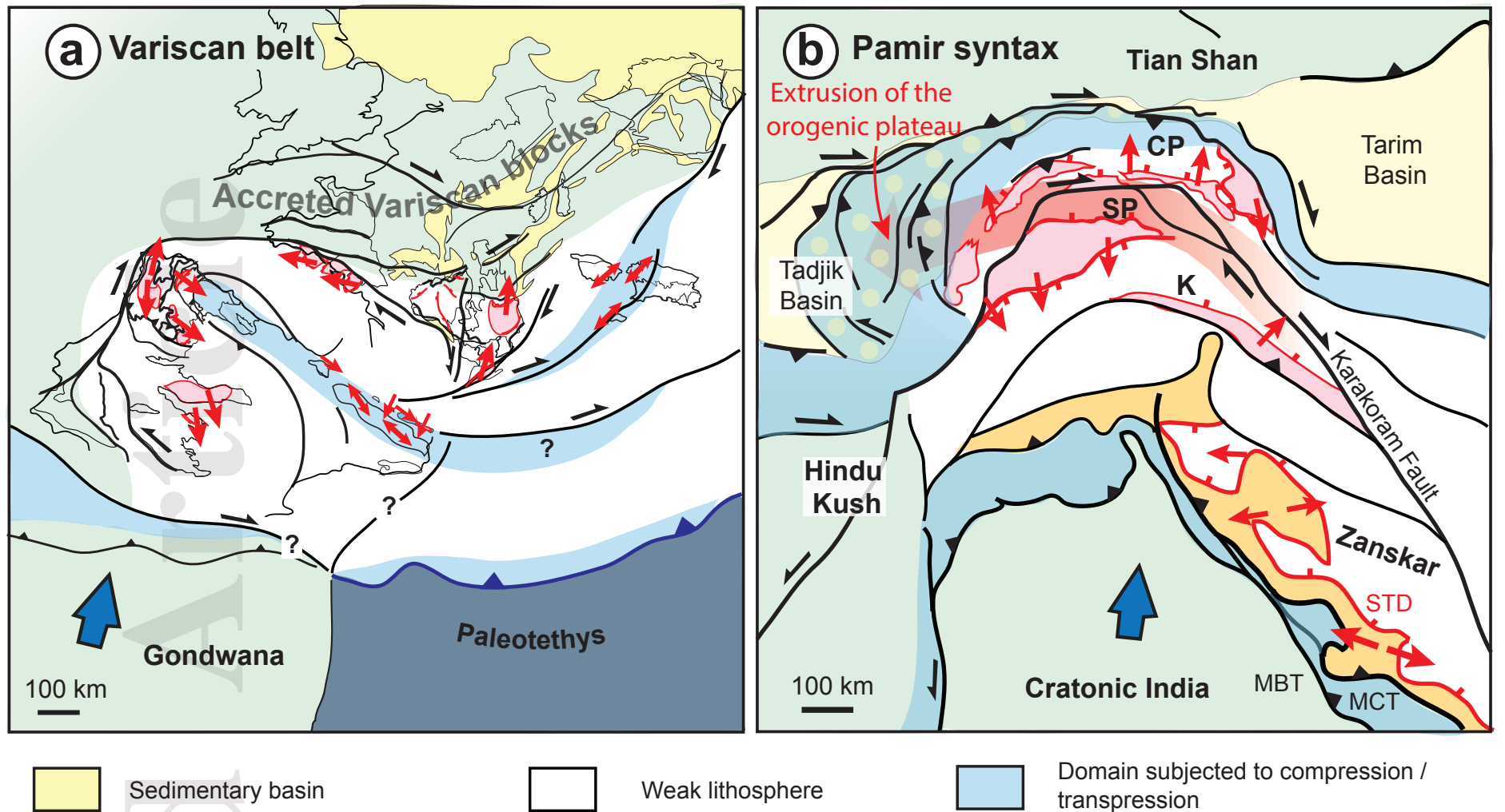

Sedimentary basin

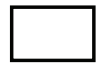

Weak lithosphere

Strong lithosphere

Gneiss dome

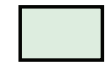

Higher Himalayan Crystalline

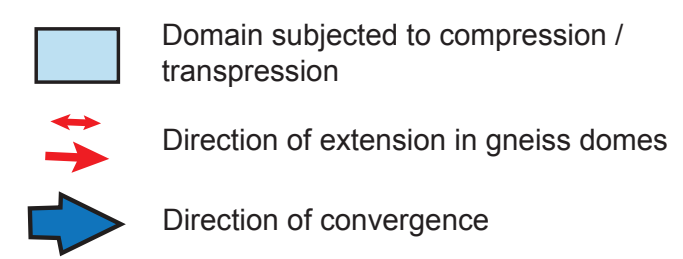

This article is protected by copyright. All rights reserved. 